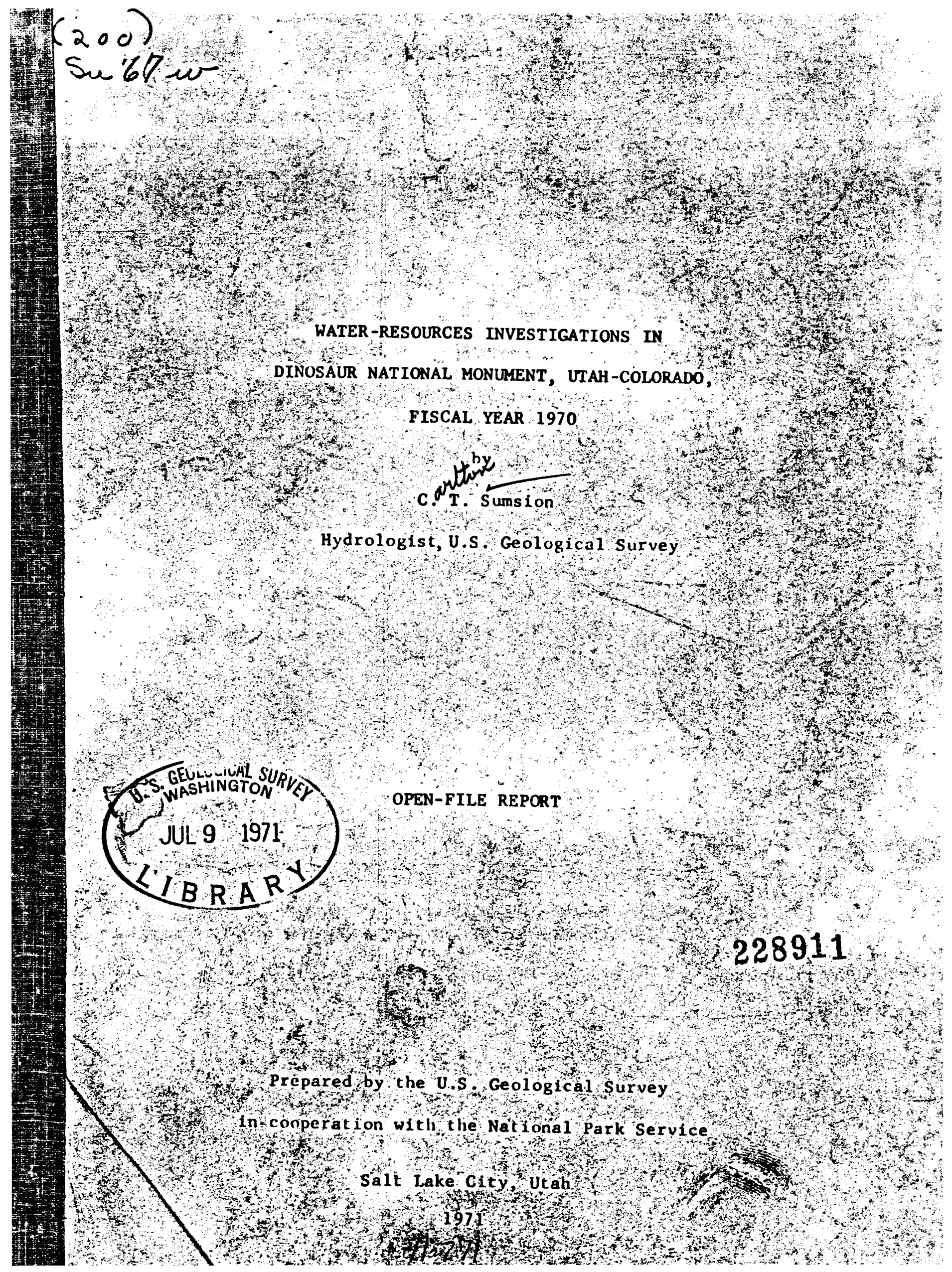


CONIENTS

Page

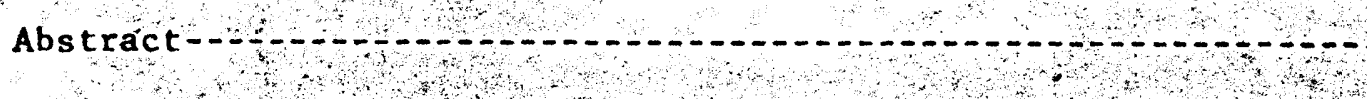

Introduction -

Areal evaluations

Deerlodge Park area-

Dinosaur Quarry area-

(t)

Gates of Lodore area

Monument Headquarters area

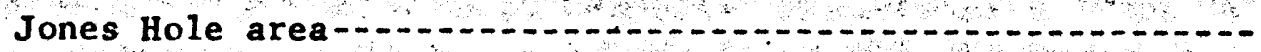

Echo Park area

Test well in the Echo Park area- 32

Summary and plans for fiscal year 1971

References $-1-0.045$

Appendix

A. Units and terminology- 47

B. We11- and spring-numbering system used in Utah-..... 51

C. We11- and spring-numbering system used in Colorado-... 52 
Figure 1-7. Maps showing:

1. Dinosaur National Monument, locations of areal evaluations, and key numbers referred to in tables -

2. Deerlodge Park area-

3. Dinosaur Quarry area-

4. Gates of Lodore area-.

5. Monument Headquarters area-

6. Jones Hole area-1. 25

7. Echo Park area-. 29

8. Diagram showing discharge-pipe installation and well-construction data for Echo Park Well 3....-

9-13. Graphs showing:

9. Recovery of artesian pressure at Echo Park Well 3,

July $7-8,1970-1$

10. Recovery curve at Echo Park Well 3, showing calculation of transmissivity-...

11. Drawdown while pumping, and recovery of the water level after pumping ceased at Echo Park Well 3--

12. Relationship of discharge to water level in Echo

Park Well 3 -

13. Increase in artesian flow after pumping ceased

at Echo Park Well 3 
Table 1. Generalized geologic sections

2. Summary data of wells and springs, Deerlodge Park area- -8

3. Chemical characteristics of water from selected wells and springs, Deerlodge Park area $\ldots \ldots \ldots \ldots \ldots \ldots \ldots \ldots \ldots$

4. Summary data of wells and springs, Dinosaur Quarry area

5. Chemical characteristics of water from selected wells and springs, Dinosaur Quarry area $\ldots \ldots \ldots \ldots$

6. Summary data of wells, Gates of Lodore area-......... 17

7. Chemical characteristics of water, from we11s, Gates of

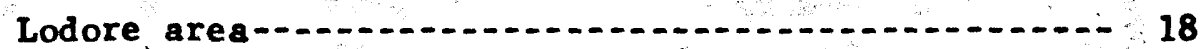

8. Summary data of we 11 , Monument Headquarters area-....- 22

9. Chemical characteristics of water from we11, Monument Headquarters area

10. Summary data of springs, Jones Hole area-........... 26

11. Chemical characteristics of water from selected springs, Jones Hole area-.

12. Summary data of wells and spring, Echo Park area-..... 30

13. Chemical characteristics of water from selected wells and spring, Echo Park area

14. Summary data of wells and springs in other areas of Dinosaur National Monument-1. 


\section{WATER-RESOURCES INVESTIGATIONS IN}

DINOSAUR NATIONAL MONUMENT, UTAH-COLORADO,

FISCAL YEAR 197.0

by

C. T. Sumsion

Hydrologist; U.S. Geological Survey

\section{ABSTRACT}

Water-resources data were acquired during fiscal year 1970 by the

U.S. Geological Survey at Dinosaur National Monument, Utah-Colorado, for the U.S. National Park Service as part of a continuing project. The data provide a basis for planning the development, management, and use of available water resources to provide adequate water supplies. Thirty-one in springs, $19_{A}$ relatively inaccessible areas, were evaluated as sources of water supplies. Seven potential well sites were evaluated for drilling depths in specific aquifers. A well drilled in Echo Park near the confluence of the Green and Yampa Rivers was tested. The pumping test showed the well to yield 130 gallons per minute with a drawdown of 1.96 feet; specific capacity of the well at 130 gallons per minute is 66 gallons per minute per foot. Water samples for chemical analysis were collected from nine springs and one we11; all except that from Disappointment Spring, were of good chemical quality. 
INTRODUCTION

This report provides water-resources data for Dinosaur National Monument that were acquired during fiscal year. 1970 by the U.S. Geological Survey on behalf of the U.S. National Park Service. The hydrologic Investigation, mainly of specific areas in Dinosaur National Monument, was part of a continuing project that will resuit in a description of the water resources in the monument. The information thus acquired is intended to serve as a basis for planning the development, management, and use of available water-resources to provide adequate water supplies within the monument.

The areas studied and the water sources inventoried in fiscal year 1970 are shown in figure 1. Many of the springs and locallties discussed or referred to in this report are in relatively inaccessible terrain, traversable only by foot tralls or by streambeds.- Springs were located and evaluated as sources of water supplies, and potential well sites were examined and evaluated in relation to existing wells and to their hydrologic and geologic setting. One well was drilled and tested in Echo Park. Water samples for chemical analys is wereftacen from nine springs and from one well. Spring and well locations are shown in figure 1 with key numbers which are given in the tables. Older chemical analyses are presented in some tables for comparison with recent data. 
hydrologic Investigations made during fiscal year 1968 included examination of we118, well sites, and springs in the Cub Creek area, Little Rainbow Park, and Rainbow Park. During fiscal year 1969 hydrologic imvestigations were made at Round Top Lookout, Harpers Corner, Island Park, Split Mountain and Green River campgrounds, and the Yampa Bench area.

The kind cooperation and assistance of Dinosaur National Monument Superintendent J. L. Dunning and his staff and of Messrs. G. S. WituckI and D. C. Barrett is gratefully acknowledged. AREAI EVALUATIONS

\section{Deerlodge Park area}

Deerlodge Park along the Yampa River is at the easternmost end of Dinosaur National Monument in Moffat County, Colo. (f1g. 1). It is accessible by 12 miles of paved road from U.S. Highway 40 .

Geologic formations in the area are 118 ted in table 1. The rocks in Deerlodge Park are exposed in a northeast-trending monocilinal fold In which strata are Inclined $10^{\circ}$ to $25^{\circ}$ southeastward (Untermann and Untermann, 1965).

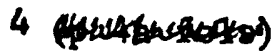

page 6 follows 
1 The National Park Service has installed two wells at Decrlodge Park (rip. 2 and iable 2): Deerlulge hell 1, an unused well 00 feel deep, is repurted t" flin about 2 bpm (galluns per.minute). The well is capped and sealcd a: present $(1970)$; it will be used in the future when a source of priwer fur pumping is available. There is no record of a pumping cest or of the specific capacity of this well. The chemical quality of water frum Deerlodge Well 1 is good (tahle 3). A decper well at this site, 500 to 600 feet deep in the Glen Canyon Sandstone, would prohably furnish the estimated water-supply requirement of Deerlndge Park, reported to be about $60 \mathrm{spm}$ (Superintendent P. R. Iversen, oral commun., 1969). Dierludge Hell 2 is $25^{\circ}$ feet deen and is equipped with a hand pump; water from this .well is not used for drinking because the water is from a shallow source and prohably is contaminated. No drinking water is available in the area at present.

A shallow d:1g well lined with stune was found in the liwer end of Disappintrent Drah, a narrow lalley west of Deerlodge Park, hut the well was iry (fig. 2 and table 2). The Weber Sandstone is exposed west of the draw, however, and wells 300 to 400 feet deep should produce good water frim tiat formation. 


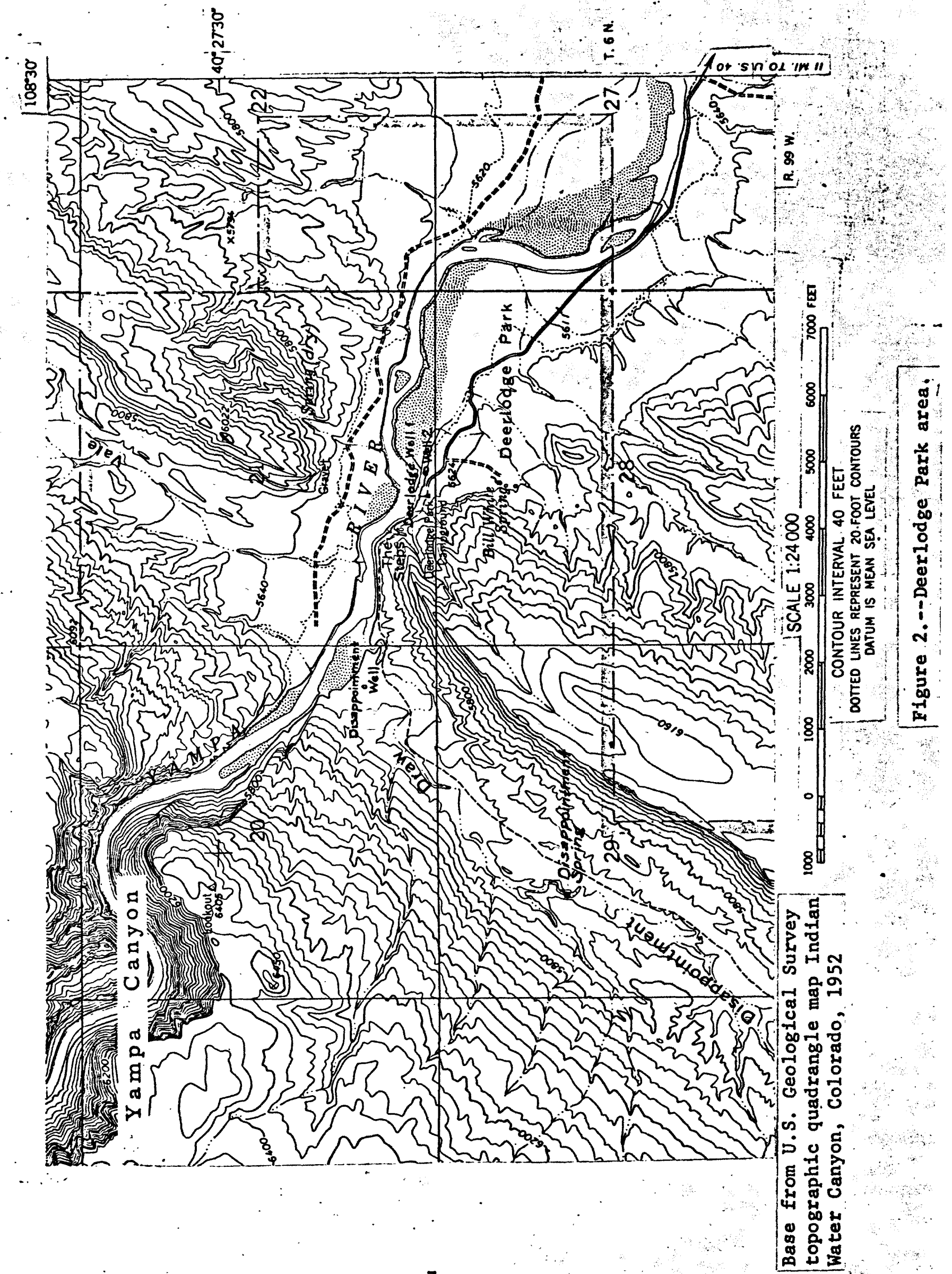




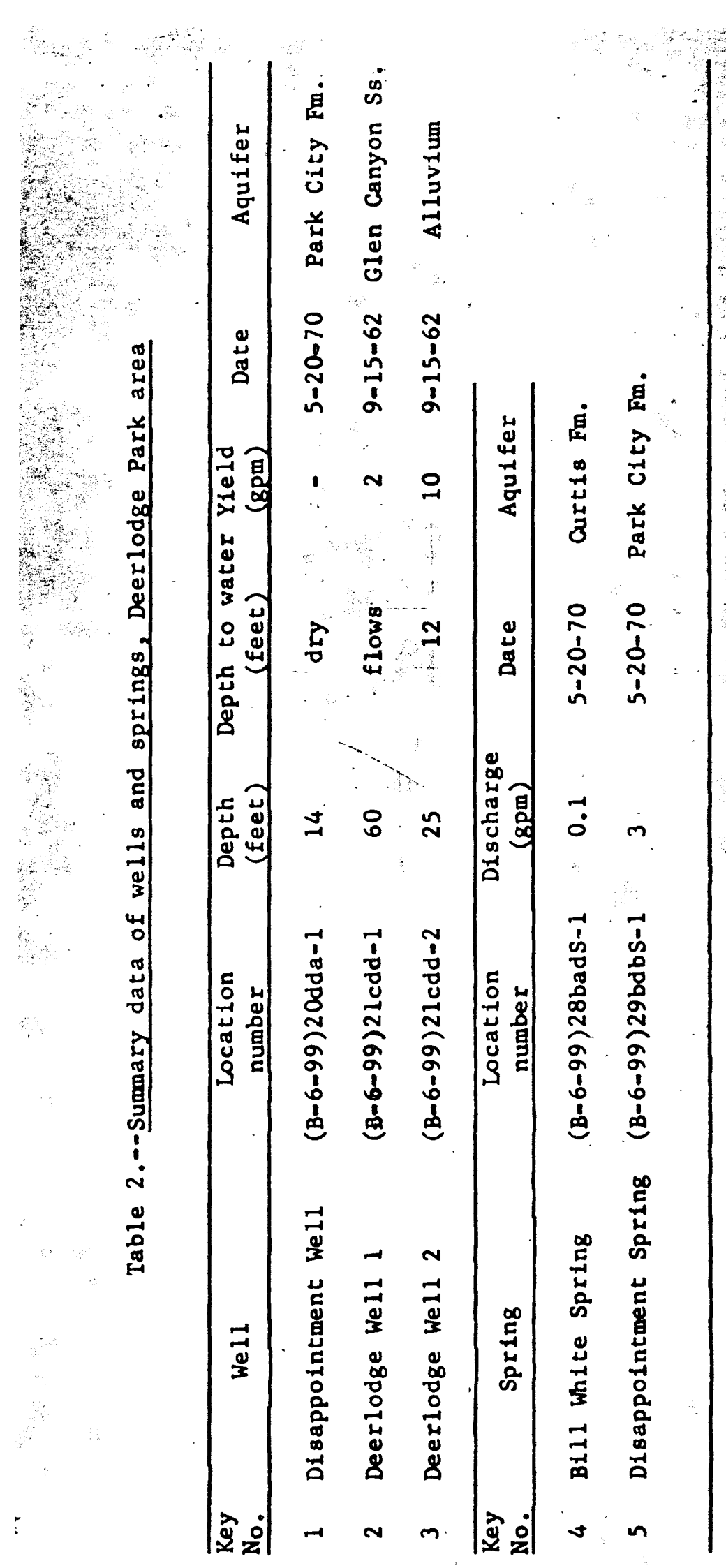


Two springs were examined in the Deerlodge Park:area, including Disappointment Draw (fig. 2 and table 2). Bill White Spring discharges very little water, but the water is of good chemical quality (table 3). Disappointment Spring also discharges very little water and it is probably suitable only for emergency use because the water contains concentrations of sulfate and dissolved solids in excess of the recominended limits of the U.S. Public Health Service (1962) (table 3).

\section{Dinosaur Quarry area}

The Dinosaur Quarry area is near the southwest corner of Dinosaur National Monument, north of Green River (figs. 1 and 3) in Uintah County, Utah. It is accessible by about 6 miles of paved road from U.S. Highway 40 at Jensen, Utah.

The Dinosaur Quarry is on an outcrop of the Morrison Formation, one of several furmations exposed on the south limb of the Split Mountain anticline (Untermann and Untermann, 1965). The strata dip southsouthwestward at $63^{\circ}$ to $67^{\circ}$ in the vicinity of the quarry. Other formations in the area are described in table 1. The sandstones in this area which would be aquifers for drilled wells are the Weber, the Glen Canyon, and the Entrada. 
Table 3.--Chemical characteristics of water from selected we11s and springs, Deerlodge Park area

Analyses are reported in milligrams per 1 iter

\begin{tabular}{|c|c|c|c|c|}
\hline . & $\begin{array}{l}\text { Deerlodge } \\
\text { We11 } 1\end{array}$ & $\begin{array}{l}\text { Bill White } \\
\text { Spring }\end{array}$ & $\begin{array}{c}\text { Disappointment } \\
\text { Spring }\end{array}$ & $\begin{array}{l}\text { PHS } \\
\text { limits }\end{array}$ \\
\hline Date of sample & $9-18-62$ & $5-20-70$ & $5-20-70$ & \\
\hline Silica $\left(\mathrm{SiO}_{2}\right)$ & 15 & 13 & 12 & - \\
\hline Calcium (Ca) & 29 & 38 & 253 & - \\
\hline Magnes I um (Mg) & 12 & 16 & 54 & - \\
\hline Sodium $(\mathrm{Na})$ & 19 & 9.9 & 16 & - \\
\hline Potassium (K) & - & 1.7 & .7 & - \\
\hline Bicarbonate $\left(\mathrm{HCO}_{3}\right)$ & 173 & 194 & 274 & - \\
\hline Sulfate $\left(\mathrm{SO}_{4}\right)$ & 19 & 15 & 608 & 250 \\
\hline Chloride (C1) & 2 & 6.0 & 3.1 & 250 \\
\hline Fluoride (F) & .1 & .2 & .3 & 1.7 \\
\hline Nitrate $\left(\mathrm{NO}_{3}\right)$ & .2 & 4.7 & .0 & 45 \\
\hline Boron (B) & - & .02 & .07 & - \\
\hline Iron $(\mathrm{Fe})$ & 1.2 & .00 & .02 & .3 \\
\hline Dissolved solids & 175 & 194 & 1,260 & 500 \\
\hline Hardness as $\mathrm{CaCO}_{3}$ & 123 & 162 & 850 & - \\
\hline Temperature, ${ }^{\circ} \mathrm{C}$ & - & 10.0 & 9.5 & - \\
\hline $\begin{array}{l}\text { Specific conductance } \\
\text { micromhos at } 25^{\circ} \mathrm{C}\end{array}$ & 301 & 341 & 1,450 & - \\
\hline $\mathrm{pH}$ & 7.7 & 7.5 & 7.8 & - \\
\hline
\end{tabular}


政

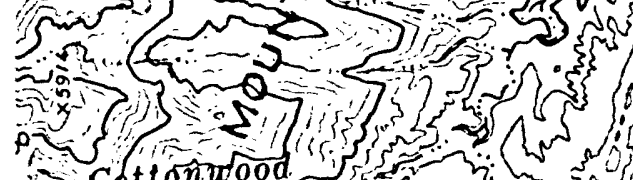
af

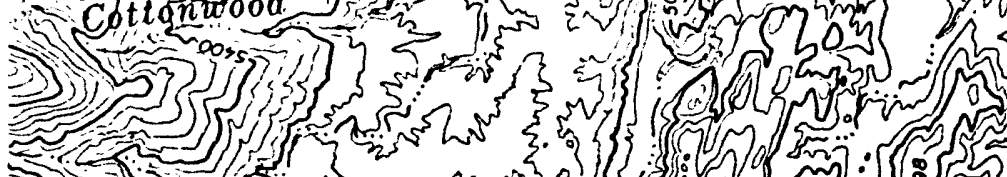

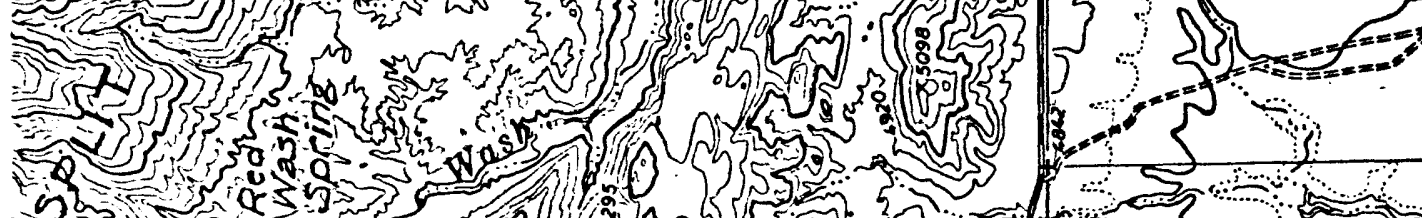

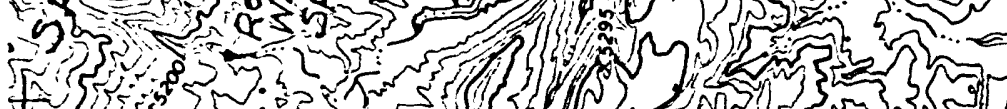
I

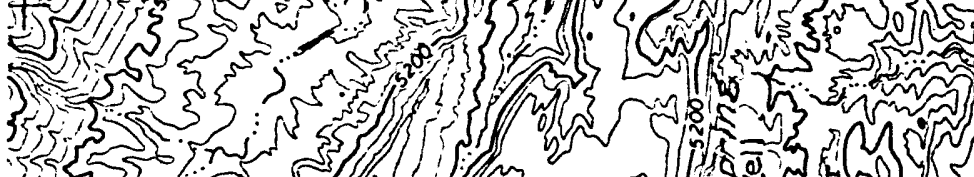

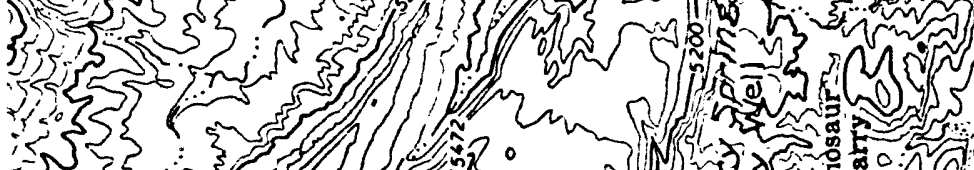

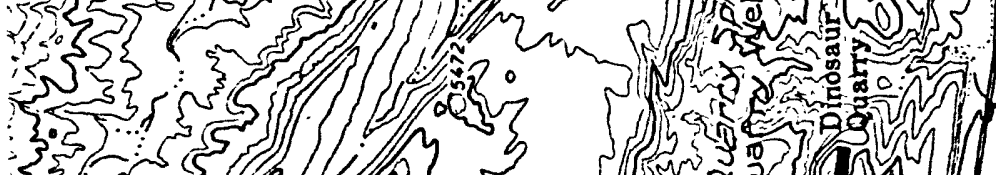
3

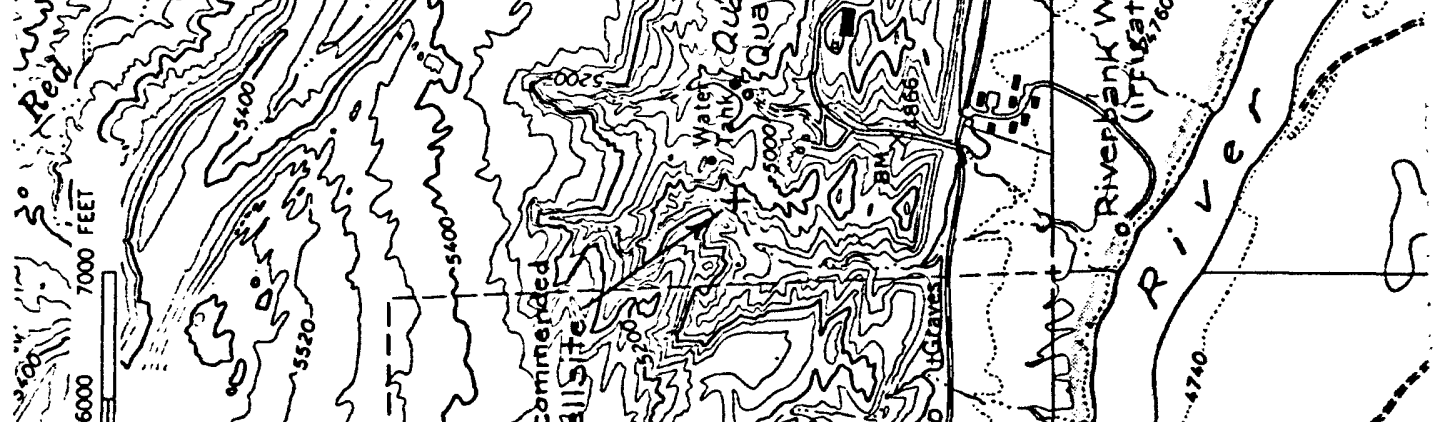

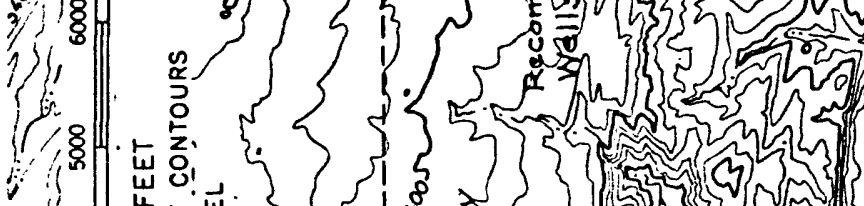

.

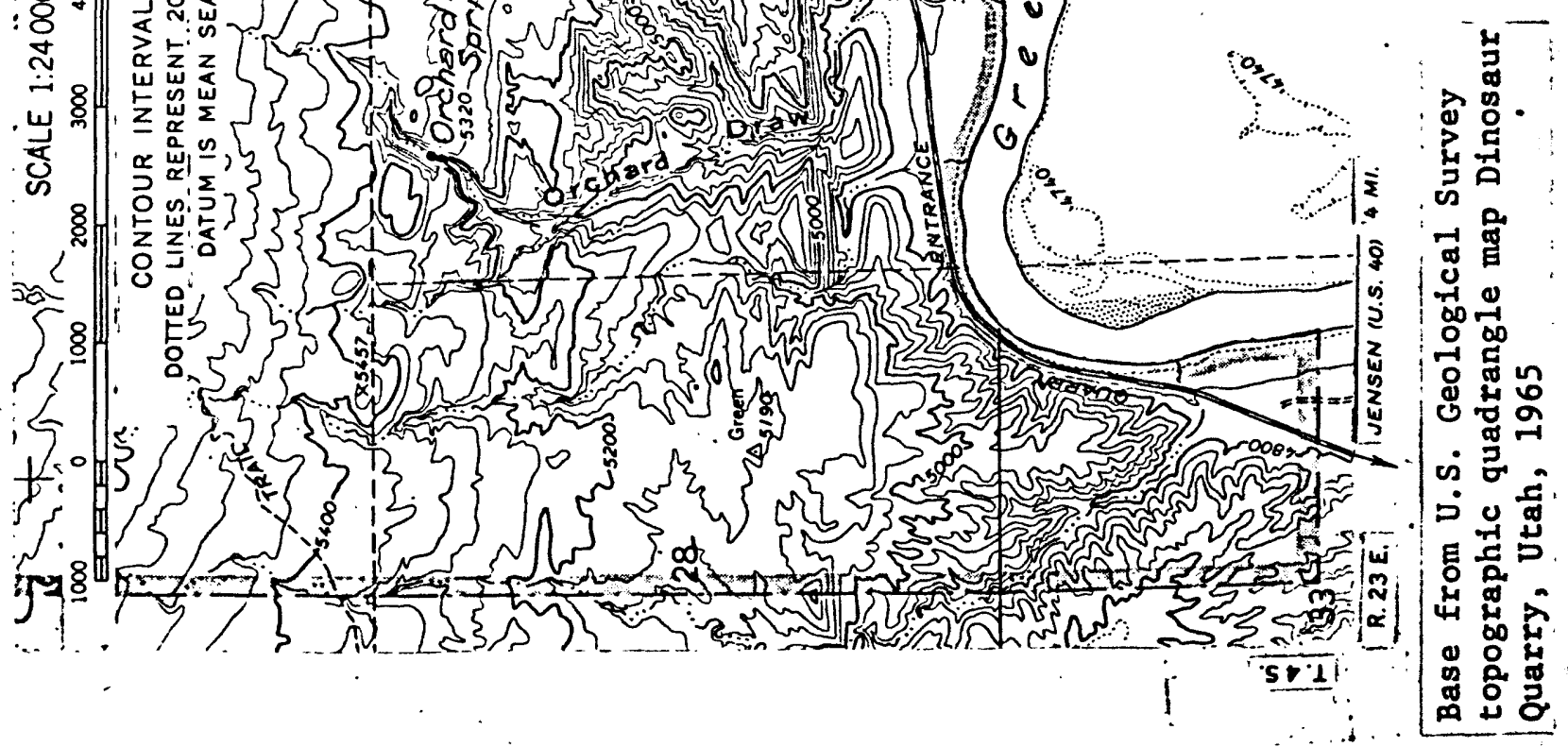


In October 1960 the National Park Service installed a well (Quarry We11) 965 feet deep (D. L. Cample11, driller, written commun., 1960) near the quarry (fig. 3 and tahle 4), which reportedly yields about $33 \mathrm{gpm}$ from the Entrada Sandstone. However, because of the thicknesses of sandstone penetrated, totaling 925 feet, the aquifer penetrated by the well probably is the Glen Canyon Sandstone. The well head is located about 70 feet from the base (in true section) of the Curtis Formation. The dip of the strata at this site is about $64^{\circ}$, and the perforated interval of the well casing, 652 to 965 feet, will fall within the Glen Canyon Sandstone. A shallow well, the Riverbank Well (fig. 3 and table 4), provides irrigation water for lawns and gardens in the Dinosaur Quarry area. It is recommended that another well be drilled, as an alternate and supplementary source of water, for public supplies in the area. The recommended well site, shown in figure 3, is about 1,000 feet west of the Quarry We11, in a small. unnamed draw west of the water tank. The estimated drilling depth is 1,0001,500 feet, most of which is in Glen Canyon Sandstone.

The use of Quarry Spring (fig. 3 and table 4), discharging about $10 \mathrm{gpm}$ at reported maximum yield, for water supplies has been discontinued. other springs in the area are too remote and do not yield sufficient water to be considered as sources of water supply.

The Quarry Well provides water of good chemical quality for its intended use (table 5). Water from the Riverbank Well has concentrations of dissolved solids and sulfate in excess of Public Health Service recommended upper limits and is suitable only for some types of irrigation, for example, lawns and gardens. Orchard Draw Spring has water of good quality (Lable 5), but it is considered to be too remote for use at the present time. 


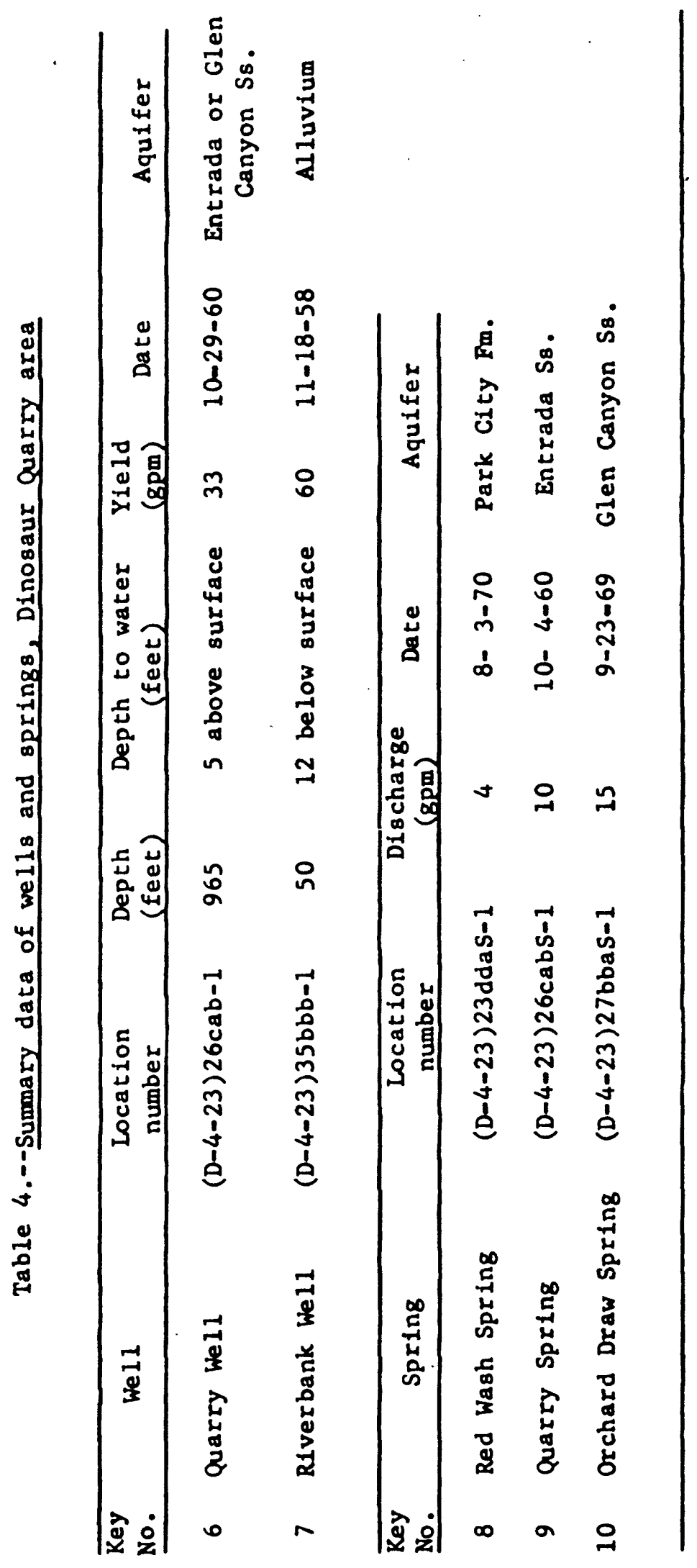


Table 5.-- Chemical characteristics of water from selected wells and spring, Dinosaur quarry area

Analyses are reported in milligrams per 11 ter

\begin{tabular}{|c|c|c|c|c|c|}
\hline & $\begin{array}{l}\text { Quarry } \\
\text { Well }\end{array}$ & $\begin{array}{c}\text { Riverbank } \\
\text { We } 11\end{array}$ & $\begin{array}{l}\text { Orchard } \\
\text { Draw Spring }\end{array}$ & $\begin{array}{c}\text { PHS } \\
\text { limits }\end{array}$ & \\
\hline Date of sample & $5-27-69$ & $11-18-58$ & $10-1-58$ & $\cdot$ & \\
\hline Silica $\left(\mathrm{SiO}_{2}\right)$ & 10 & 16 & 11 & - & \\
\hline Calcium (Ca) & 33 . & 361 & 67 & - & \\
\hline Magnesi um (Mg) & 23 & 216 & 26 & - & \\
\hline Sod1um (Na) & 35 & 532 & 11 & - & \\
\hline Potassium (K) & 3.6 & - & - & - & \\
\hline Bicarbonate $\left(\mathrm{HCO}_{3}\right)$ & 242 & 212 & 223 & - & \\
\hline Sulfate $\left(\mathrm{SO}_{4}\right)$ & 45 & 2,590 & 102 & 250 & \\
\hline Chloride (Cl) & 9.4 & 55 & 5 & 250 & \\
\hline Fluoride (F) & .3 & 1.8 & .0 & 1.7 & . \\
\hline Nitrate $\left(\mathrm{NO}_{3}\right)$ & 1.2 & .8 & .6 & 45 & \\
\hline Boron (B) & .05 & - & - & - & \\
\hline Iron $(\mathrm{Fe})$ & .04 & .15 & - & .3 & \\
\hline Dissolved solids & 270 & 3,870 & - & 500 & \\
\hline Hardness as $\mathrm{CaCO}_{3}$ & 176 & 1,790 & 273 & - & \\
\hline Temperature, ${ }^{\circ} \mathrm{C}$ & 12.0 & 12.0 & 16.0 & - & \\
\hline $\begin{array}{l}\text { Specific conductance, } \\
\text { micromhos at } 25^{\circ} \mathrm{C}\end{array}$ & 462 & 4,400 & 529 & - & \\
\hline $\mathrm{pH}$ & 8.0 . & 7.5 & 7.8 & - & \\
\hline
\end{tabular}




\section{Gates of Lodore area}

The Gates of Lodore area lies in the northernmost part of Dinosaur National Monument near the head of Lodore Canyon (figs. 1 and 4) in Moffat County, Colo. It is accessible by about $10 \mathrm{miles}$ of unpaved but improved road from Colorado State Highway 318.

It is estimated that the water-supply requirements of the area will be about 35 to $50 \mathrm{gpm}$ in the near future. The present water supply, $35 \mathrm{gpm}$, may be insufficient when the access road is paved and visitors to the area increase in numbers. Facilities of the area include a ranger station and residence, a maintenance compound (presently unused), and a campground with a boat-launching ramp.

South of the Gates of Lodore, the Green River canyon walls rise abruptly from the water's edge. About 2 river miles downstream from the ranger station, the canyon $\mathrm{rim}$ is more than 1,000 feet above the river (fig. 4). The Uinta Mountain Group, Browns Park Formation, and alluvium of the Green River underlie the campground and ranger station (table 1). In the Gates of Lodore area, the Browns Park Formation probably does not exceed 300 feet in thickness (table 1). The maximum reported thickness of the Browns Park Formation is about 1,200 feet (Uhtermann and Untermann, 1965). The formation dips gently northeastward in this area, overlapping the Uinta Mountain Group. 


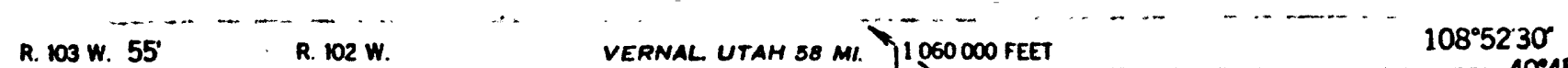

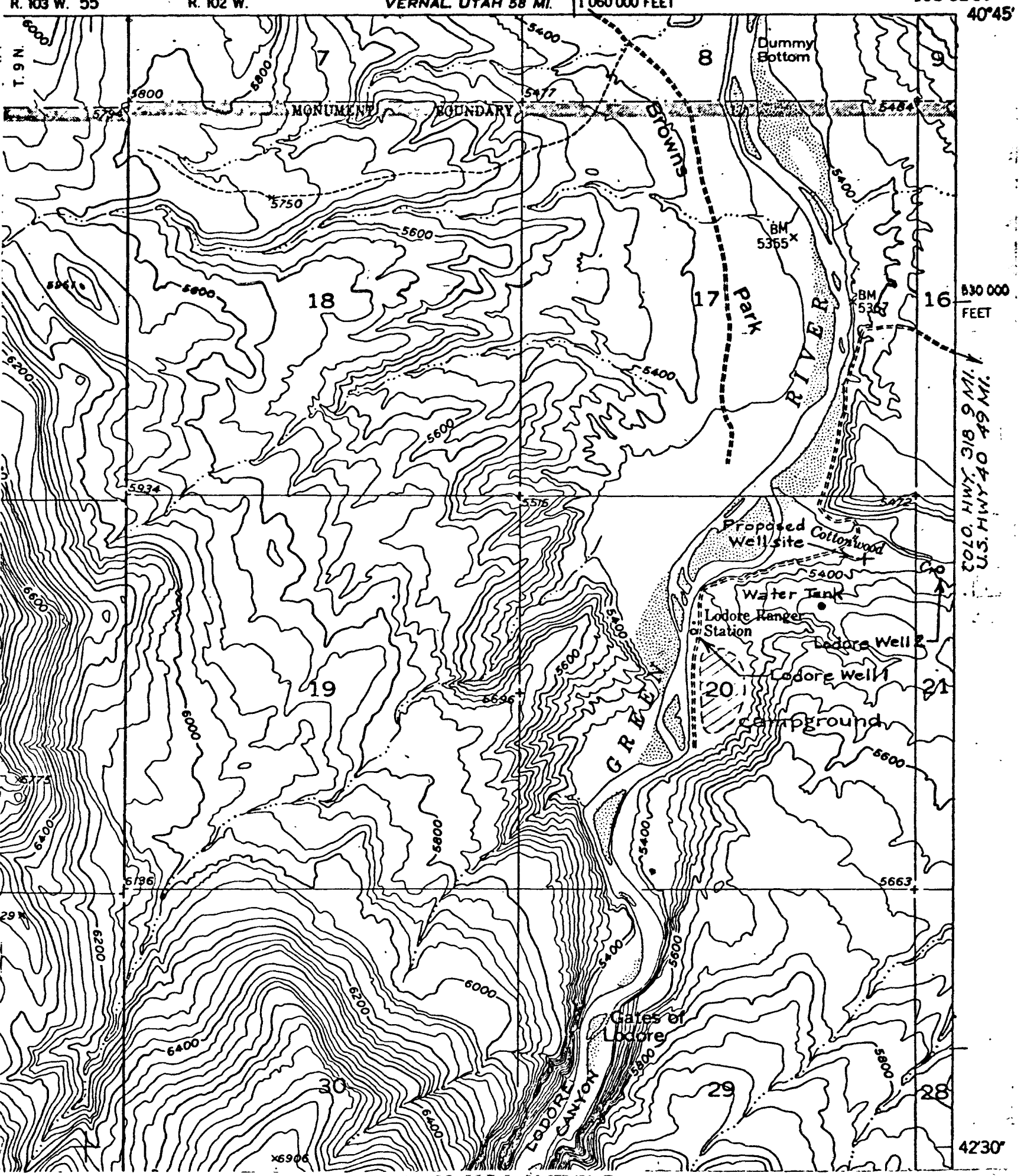

SCALE 1:24000

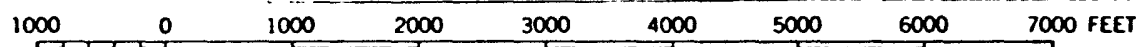

Base from U.S. Geological Survey topographic map Canyon of Lodore North, Colorado, 1954
CONTOUR INTERVAL 40 FEET

DATUM IS MEAN SEA LEVEL

Figure 4.--Gates of Lodore area. 


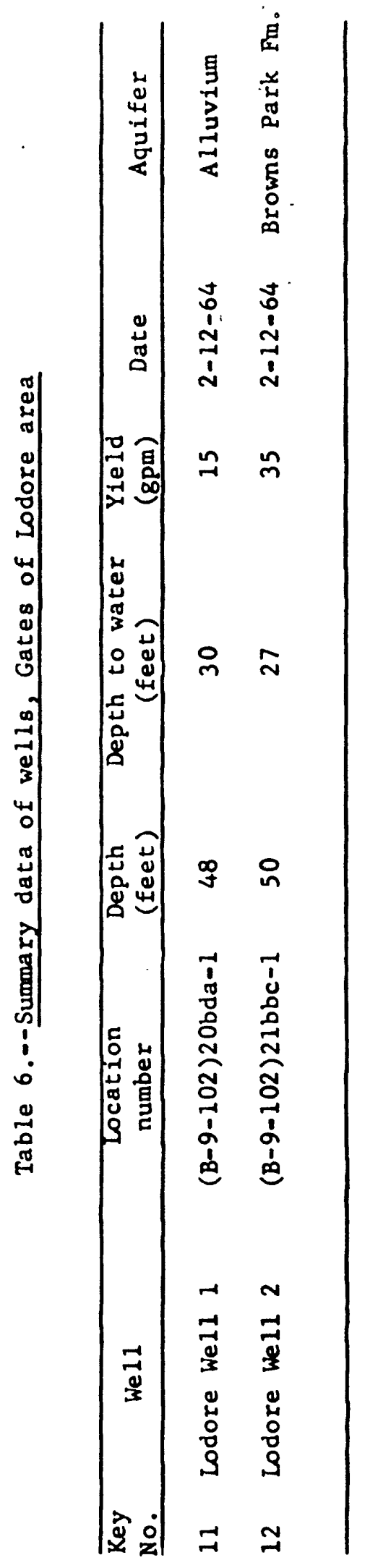


Table 7.--Chemical characteristics of water from wells,

Gates of Lodore area

Analyses are reported in milligrams per 1 iter

\begin{tabular}{|c|c|c|c|}
\hline & $\begin{array}{l}\text { Lodore } \\
\text { We } 111\end{array}$ & $\begin{array}{l}\text { Lodore } \\
\text { We11 } 2 \\
\end{array}$ & $\begin{array}{c}\text { PHS } \\
\text { limits }\end{array}$ \\
\hline Date of sample & $2-12-64$ & $9-24-69$ & - \\
\hline $\operatorname{Silica}\left(\mathrm{SiO}_{2}\right)$ & 37 & 44 & - \\
\hline Calcium (Ca) & 26 & 67 & - \\
\hline Magnesium (Mg) & 16 & 36 & - \\
\hline Sodium (Na) & 242 & 39 & - \\
\hline Potassium (K) & - & 6.7 & - \\
\hline Bicarbonate $\left(\mathrm{HCO}_{3}\right)$ & 372 & 301 & - \\
\hline Sulfate $\left(\mathrm{SO}_{4}\right)$ & 222 & 115 & 250 \\
\hline Chloride (Cl) & 78 & 30 & 250 \\
\hline Fluoride (F) & 2.3 & .7 & 1.7 \\
\hline Nitrate $\left(\mathrm{NO}_{3}\right)$ & 2.5 & 1.5 & 45 \\
\hline Boron (B) & - & .10 & - \\
\hline Iron (Fe) & - & .02 & .3 \\
\hline Dissolved solids & 809 & 521 & $\underline{1} / 500$ \\
\hline Hardness as $\mathrm{CaCO}_{3}$ & 128 & 316 & - \\
\hline Temperature, ${ }^{\circ} \mathrm{C}$ & 12.0 & 12.0 & - \\
\hline $\begin{array}{l}\text { Specific conductance, micromhos } \\
\text { at } 25^{\circ} \mathrm{C}\end{array}$ & 1,200 & 733 & - \\
\hline pH & 8.2 & 8.0 & - \\
\hline
\end{tabular}

1/ Recommended limit $500 \mathrm{mg} / 1$, tolerable 1 imit $1,000 \mathrm{mg} / 1$. 
The National Park Service has installed two wells in the Gates of Lodore area (fig. 4, tables 6 and 7). The first of these, Lodore Well 1 , penetrated alluvium of the Green River.' This well was abandoned because the chemical quality of the water was unsatisfactory. The second well, Lodore Well 2, yields about $35 \mathrm{gpm}$ from the Browns Park Formation. Drilling of a third well is suggested as an alternate and supplementary source of water supply to meet increased water-supply near

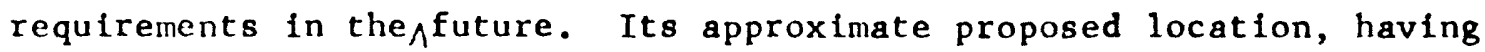
the same terrane as Lodore Well 2, is shown in figure 4. There are no springs in the near vicinity of the Lodore Ranger Station. The Browns Park Formation is the only aquifer in the Cates of Lodore area capable of yielding sufficient good-quality water for development.

\section{Monument Headquarters area}

The Dinosaur National Monument Headquarters area is about 2 miles east of Dinosaur, Colob, adjacent to U.S. Highway 40 in Moffat County, Colo. (figs. 1 and 5).

The area is on the south 1 imb of the Plue Mountain anticline (Cullins, 1969); a monoclinal fold that strikes east, and dips $28^{\circ}$ to $52^{\circ}$ southward. The formations exposed in the Monument Headquarters area are listed and described in table 1. The principal aquifer underlying the Monument Headquarters area is the Glen Canyon Sandstone. 
In 1962, the National Park Service installed one well, the Headquarters We11, 800 feet deep (fig. 5, table 8). The well ubtains water from the Glen Canyon Sandstone. The chemical quality of water is good for its intended uses (table 9). A second well should be installed, as an alternate in the event of pump failure and as a supplementary source of water at periods of peak demand. A decline in the yield of the Headquarters Well to about 50 percent of the original yield owing to pump failure has been experienced (Superintendent P. R. Iversen, oral commun., 1970). The pump has since been replaced. A well site east of the maintenance area, shown as a proposed well site in figure 5, was examined; the required drilling depth would be about 2,100 feet. An alternate site, shown as an alternate well site in figure 5, is about 1,000 feet west of the Headquarters We 11 ; the required drilling depth would be about 800 to 1,000 feet.

There are no springs in the near vicinity of Dinosaur National Monument headquarters.

\section{Jones Hole area}

The Jones Hole area is in the west-central part of Dinosaur National Monument in Uintah County, Utah (fig. 1). Jones Hole Creek Canyon represents the lower continuation of Diamond Gulch. The Jones Hole area is accessible by boat from the Green River or by about $40 \mathrm{mlles}$ of secondary roads, paved and improved, from State Highway 44 in Vernal, Utah. Jones Hole Creek Canyon is traversable only by foot trails (fig. 6). 


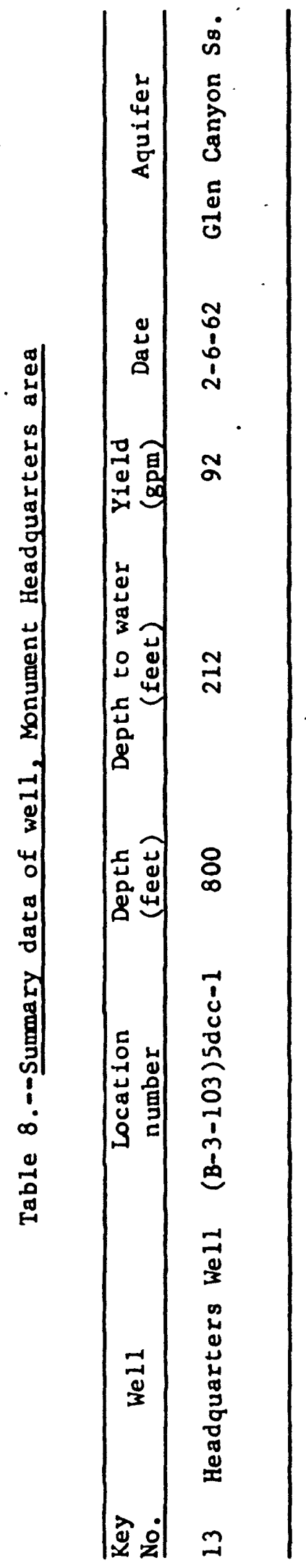


Geologic formations exposed in the Jones Hole area are listed and described in table 1. Cliff-forming strata of the Cambrian Lodore. Formation, undifferentiated rocks of Mississippian age, and the Morgan Formation and the Weber Sandstone of Pennsylvanian and Permian age rise in vertical steps above Jones Hole Creek. The nearly vertical Island Park fault (not shown on map) trending northeastward, transects the central part of Jones Hole Creek Canyon (Untermann and Untermann, 1965). Except where locally deformed by the Island Park fault, strata in the Jones Hole area dip gently southwestward. The principal aquifers in the Jones Hole area are the Morgan Formation and the Weber Sandstone.

A campground and a ranger station are located at the mouth of Jones Hole Creek. The campground is most commonly used by river travelers (fig. 6). Water for all uses here has been taken directly from Jones Hole Creek. If, with increasing use of the area by visitors and others, the water in Jones Hole Creek should become unsatisfactory because of contamination, an alternate source of water may be obtained from Big Draw Spring (fig. 6, table 10). Obtaining ground water from wells drilled in the Morgan Formation or the Weber Sandstone to about 300 feet in depth north of the Island Park fault seems feasible; however, there are no roads in Jones Hole Creek Canyon, and potential well sites are presently inaccessible to drilling equipment.

The chemical quality of water from Jones Hole and Big Draw Springs is very good (fig. 6, table 11). Water from Jones Hole Creek is also of very good chemical quality. 
Table 9.--Chemical characteristics of water from Headquarters well, Monument Headquarters area

Analyses are reported in milligrams per liter

\begin{tabular}{|c|c|c|}
\hline & $\begin{array}{c}\text { Headquarters } \\
\text { Well }\end{array}$ & $\begin{array}{c}\text { PHS } \\
\text { linits }\end{array}$ \\
\hline Date of sample & $5-26-69$ & $\cdot$ \\
\hline Silica $\left(\mathrm{SiO}_{2}\right)$ & 14 & - \\
\hline Calcium (Ca) & 57 & - \\
\hline Magnesium (MB) & 39 & - \\
\hline Sodium (Na) & 22 & - \\
\hline Potassium (K) & 2.0 & - \\
\hline Bicarbonate $\left(\mathrm{HCO}_{3}\right)$ & 303 & - \\
\hline Sulfate $\left(\mathrm{SO}_{4}\right)$ & 72 & 250 \\
\hline Chloride (C1) & 20 & 250 \\
\hline Fluoride (F) & .1 & 1.7 \\
\hline Nitrate $\left(\mathrm{NO}_{3}\right)$ & 1.3 & 45 \\
\hline Boron (B) & .00 & - \\
\hline Iron $(\mathrm{Fe})$ & .20 & .3 \\
\hline Dissolved solids & 371 & 500 \\
\hline Hardness as $\mathrm{CaCO}_{3}$ & 302 & - \\
\hline Temperature, ${ }^{\circ} \mathrm{C}$ & 13.0 & - \\
\hline $\begin{array}{l}\text { Specific conductance, } \\
\text { micromhos at } 25^{\circ} \mathrm{C}\end{array}$ & 614 & - \\
\hline pH & 7.9 & - \\
\hline
\end{tabular}




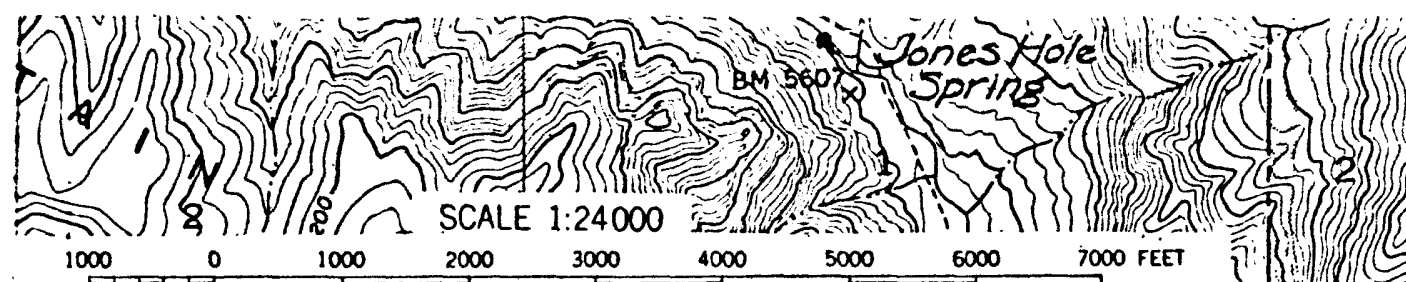

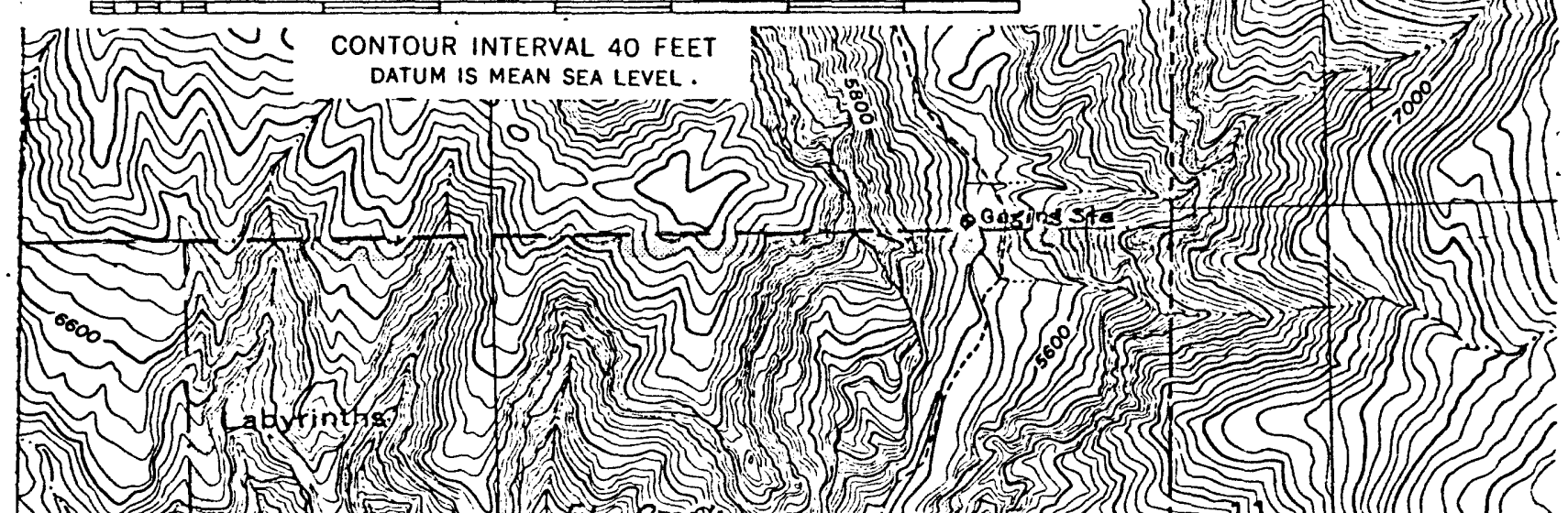

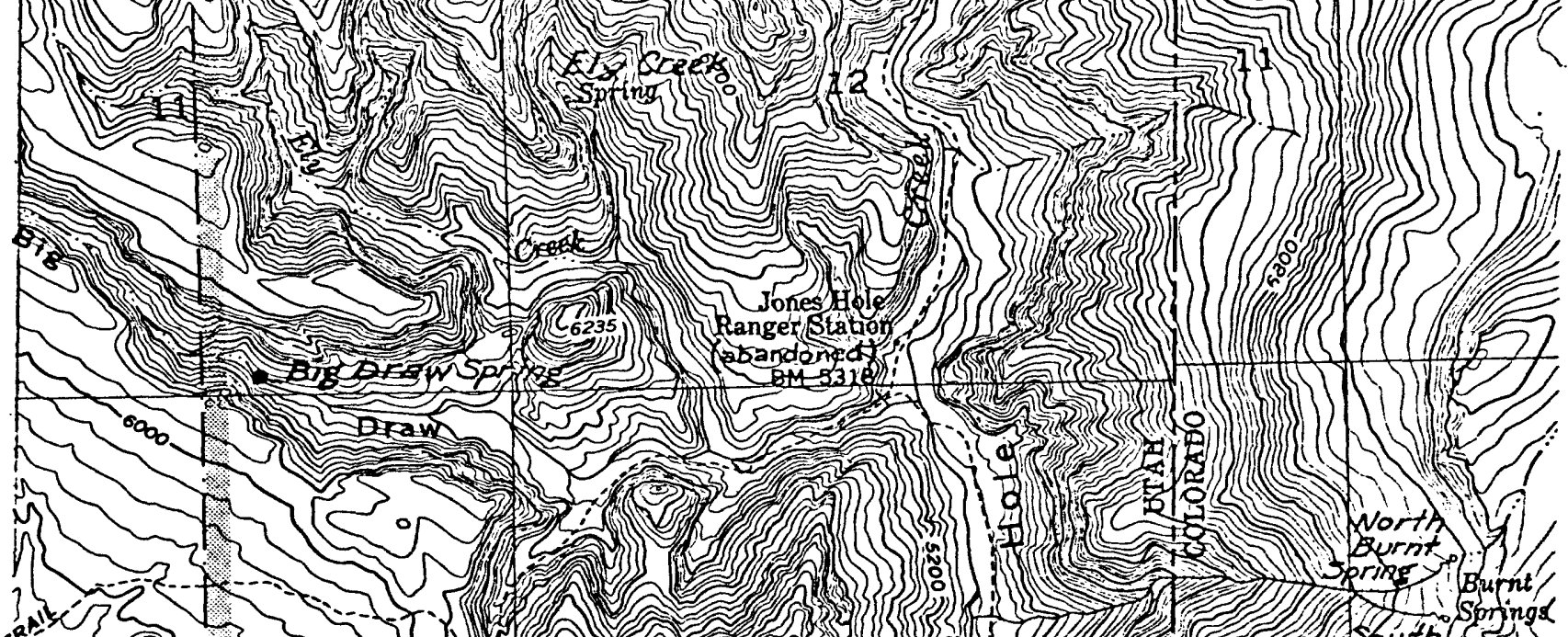

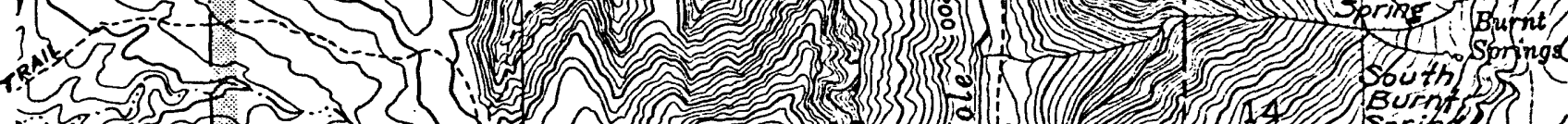

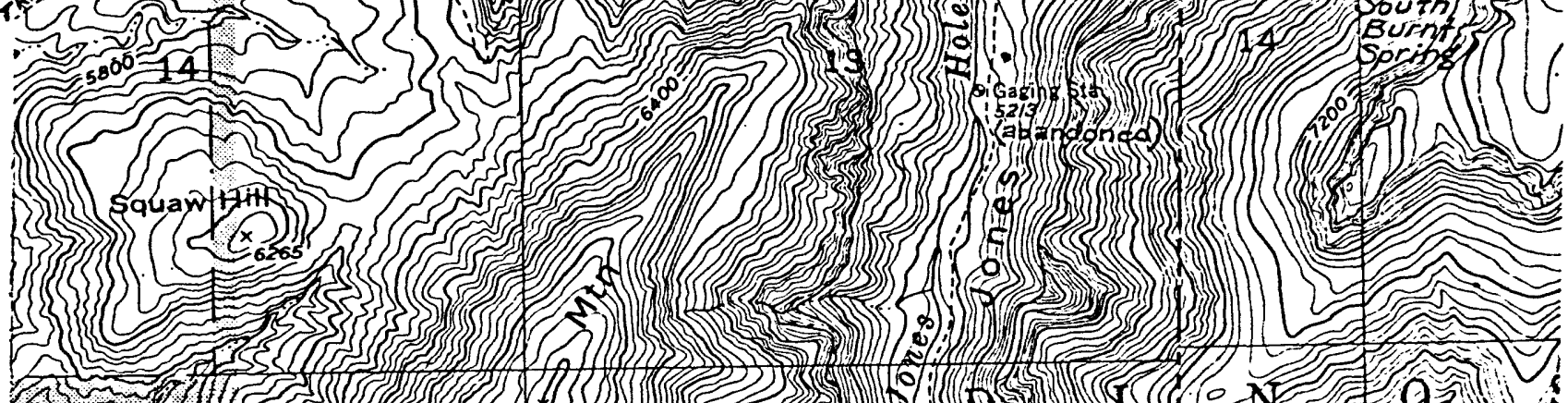
(35\}) Base from U.S. Geological Survey topographic quadrangle map Jones Hole, Utah-Colorado, 1955 


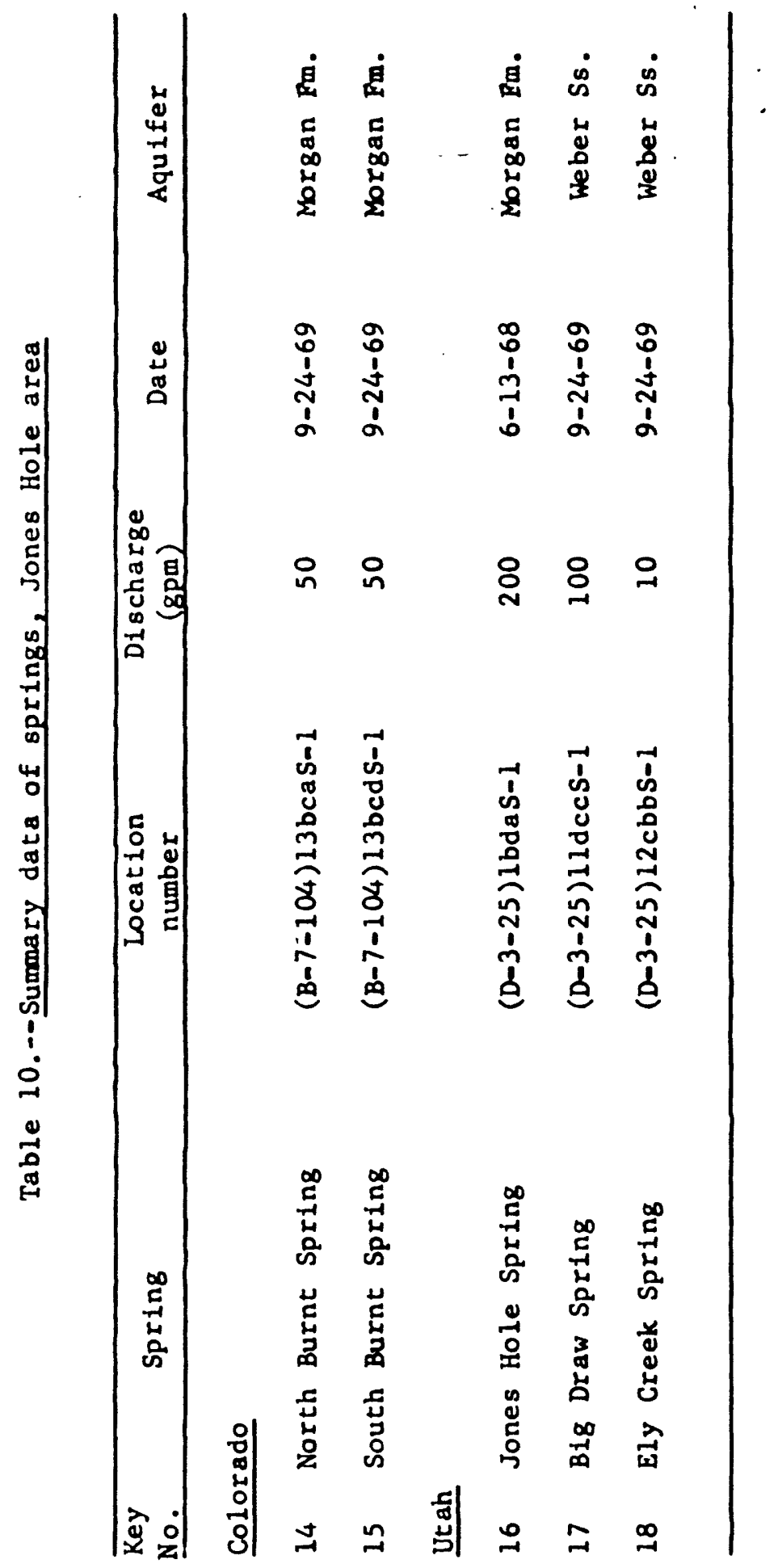




\section{Echo Park area}

Echo Park lies at the confluence of the Green and Yampa Rivers in Moffat County, Colo. (fig. 1). The Echo Park area is accessible by about 38 miles of paved and unpaved roads from Dinosaur National Monument Headquarters. Echo Park is within a deeply incised meander of the Green River (fig. 7). Nearly vertical cliffs of Weber Sandstone (table 1) rise more than 600 feet above the valley floor.

The park is about a quarter of a square mile in area. A campground and a ranger station are near the north end. Estimated water-supply requirements are presently about $15 \mathrm{gpm}$, but as numbers of visitors to the area increase, water-supply requirements may increase to about $35 \mathrm{gpm}$. Alluvium is as much as 58 feet thick at Echo Park. The National Park Service installed two shallow wells, Echo Park We11s 1 and 2, in alluvium at the Echo Park campground (fig. 7, table 12). Echo Park. Well 2 was subsequently abandoned. Echo Park Well 1 is equipped with a hand pump and is reported to yield insufficlent quantities of water during periods of peak demand (Maintenance Superintendent Graham Liles, oral commun., 1969). Mitten Fault Spring and a shallow well at Box Elder Park provide water for river travelers in the Echo Park area (fig. 7, table 12). Chemical characteristics of water from the spring and selected shallow wells are given in table 13 . 
Table 11.--Chemical characteristics of water from selected springs, Jones Hole area Analyses reported in milligrams per liter

\begin{tabular}{|c|c|c|c|}
\hline & $\begin{array}{c}\text { Jones Hole } \\
\text { Spring }\end{array}$ & $\begin{array}{l}\text { Big Draw } \\
\text { Spring }\end{array}$ & $\begin{array}{l}\text { PHS } \\
\text { 11mits }\end{array}$ \\
\hline Date of sample & $6-13-68$ & $9-24-69$ & \\
\hline Silica $\left(\mathrm{SiO}_{2}\right)$ & 13 & 11 & - \\
\hline Calcium (Ca) & 38 & 46 & - \\
\hline Magnesium (Mg) & 18 & 28 & - \\
\hline Sodium (Na) & 2.7 & 4.8 & - \\
\hline Potassium (K) & .9 & 1.6 & - \\
\hline Bicarbonate $\left(\mathrm{HCO}_{3}\right)$ & 204 & 237 & - \\
\hline Sulfate $\left(\mathrm{SO}_{4}\right)$ & 8.8 & 42 & 250 \\
\hline Chloride (Cl) & 2.2 & 4.4 & 250 \\
\hline Fluoride (F) & .4 & .3 & 1.7 \\
\hline Nitrate $\left(\mathrm{NO}_{3}\right)$ & .1 & .8 & 45 \\
\hline Boron (B) & .04 & .04 & - \\
\hline Iron (Fe) & .06 & .03 & .3 \\
\hline Dissolved solids & 178 & 280 & 500 \\
\hline Hardness as $\mathrm{CaCO}_{3}$ & 172 & 232 & - \\
\hline Temperature, ${ }^{\circ} \mathrm{C}$ & 12.0 & 12.0 & - \\
\hline $\begin{array}{l}\text { Specific conductance, } \\
\text { micromhos at } 25^{\circ} \mathrm{C}\end{array}$ & 320 & 439 & - \\
\hline pH & 7.7 & 8.2 & - \\
\hline
\end{tabular}




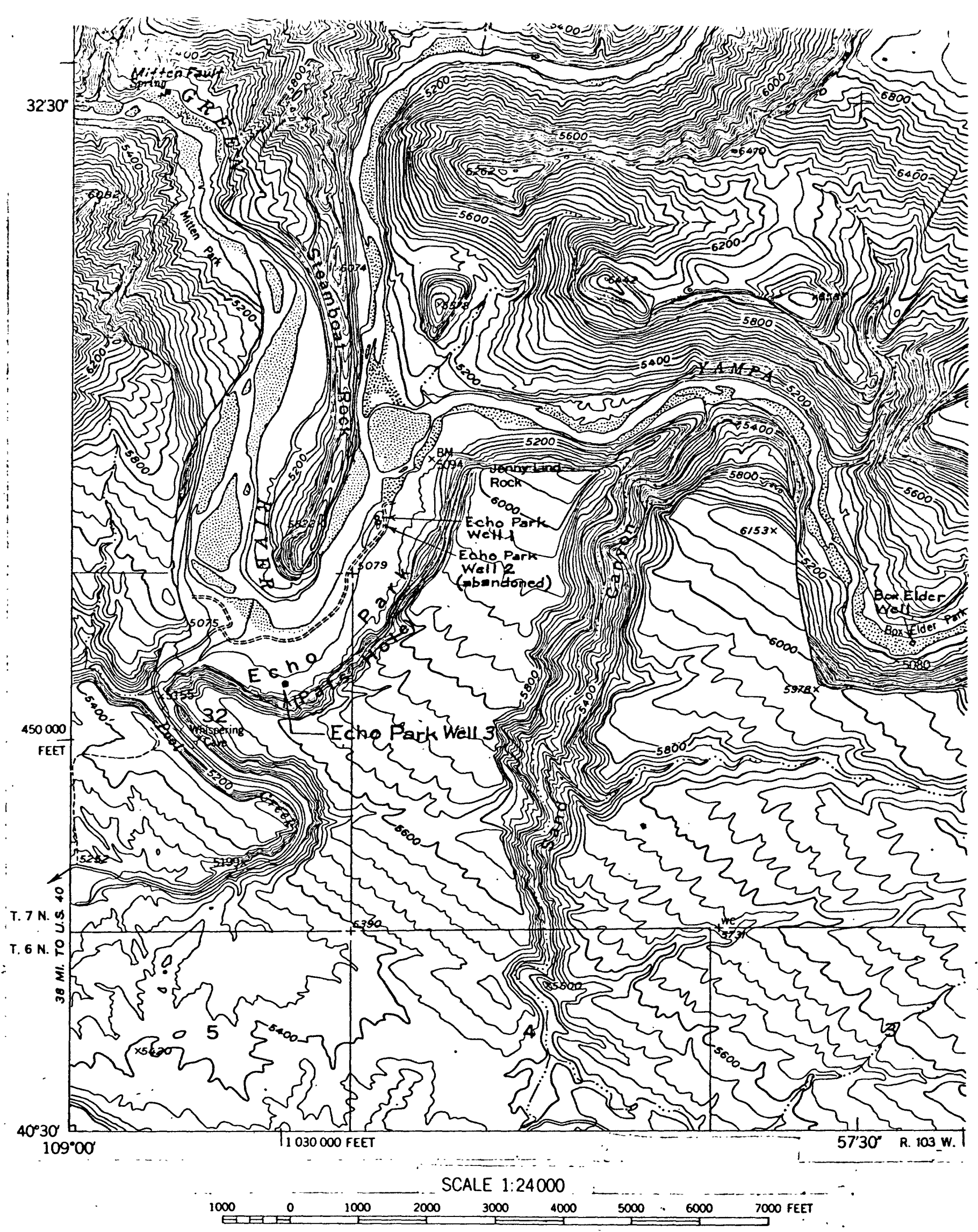

Base from U.S. Geological Survey CONTOUR INTERVAL 40 FEET topographic quadrangle map Canyon! . . DATUM IS MEA SEA LEVEL of Lodore South, Colorado, 1954

Figure 7.--Echo Park area. 


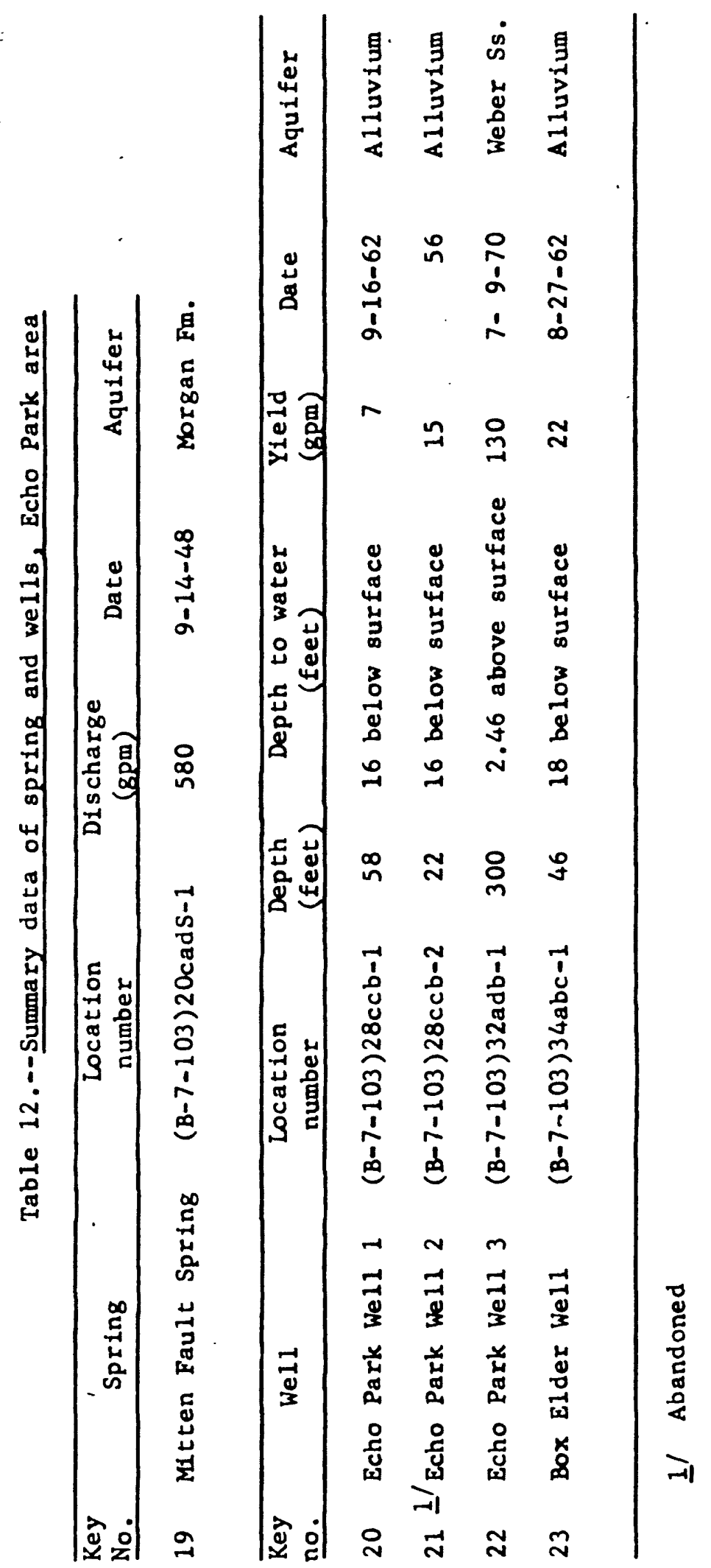


Table 13.--Chemical characteristics of water from selected spring and we118, Echo Park area

Analyses are reported in milligrams per liter

\begin{tabular}{|c|c|c|c|c|c|c|}
\hline & $\begin{array}{r}\text { Mitten F } \\
\text { Spring } \\
\end{array}$ & ult & $\begin{array}{l}\text { Echo Park } \\
\text { We 11 } 1\end{array}$ & $\begin{array}{l}\text { Box́ E1der } \\
\text { We11 }\end{array}$ & $\begin{array}{l}\text { Echo Park } \\
\text { We } 113 \\
\end{array}$ & $\begin{array}{l}\text { PHS } \\
\text { limits }\end{array}$ \\
\hline Date of sample & $9-14-48$ & $:$ & $5-27-69$ & $7-28-62$ & $7-9-70$ & \\
\hline Silica $\left(\mathrm{SiO}_{2}\right)$ & 13 & & 7.8 & 11 & 10.0 & - \\
\hline Calcium (Ca) & 74 & & 51 & 64 & 66 & - \\
\hline Magnesium (Mg) & 29 & & 29 & 15 & 36 & - \\
\hline Sodium (Na) & 237 & & 14 & 59 & 7.8 & - \\
\hline Potassium (K) & - & & 2.3 & - & 1.9 & - \\
\hline Bicarbonate $\left(\mathrm{HCO}_{3}\right)$ & 239 & & 230 & $\therefore 1$. & 239 & - \\
\hline Sulfate $\left(\mathrm{SO}_{4}\right)$ & 94 & & 68 & 102 & 108 & 250 \\
\hline Chloride (C1) & 370 & & 14 & 48 & 7.5 & 250 \\
\hline Fluoride (F) & - & & .4 & - & .04 & 1.7 \\
\hline Nitrate $\left(\mathrm{NO}_{3}\right)$ & 3 & & 2.3 & .2 & .5 & 45 \\
\hline Boron (B) & - & & .04 & - & .02 & - \\
\hline Iron (Fe) & - & & .10 & - & .04 & .3 \\
\hline Dissolved solids & - & & 304 & 396 & 373 & 500 \\
\hline Hardness as $\mathrm{CaCO}_{3}$ & 304 & & 246 & 220 & 312 & - \\
\hline Temperature, ${ }^{\circ} \mathrm{C}$ & - & & 12.0 & - & 13.5 & - \\
\hline $\begin{array}{l}\text { Specific conductanc } \\
\text { micromhos at } 25^{\circ} \mathrm{C}\end{array}$ & : & & 511 & 666 & 576 & - \\
\hline $\mathrm{pH}$ & - & & 7.9 & 7.9 & 7.6 & - \\
\hline
\end{tabular}


Test well in the Echo Park area.

Recommendations for drilling a third well at Echo Park were presented in a memorandum of September 19, 1967,. by the U.S. Geological Survey to the National Park Service. The recommended well site at Echo Park is in the NW $\frac{1}{2}$ SE $\frac{1}{2}$ NE $\frac{1}{4}$ sec. 32, T. 7 N., R. 103 W., Sixth principal base line and meridian. Altitude of the well site, interpolated from the U.S. Geological Survey topographic map of the area, is about 5,090 feet (fig. 7). The site area is underlain by alluvium and by fractured Weber Sandstone.

Drilling of Echo Park Well 3 began on June 19, 1970. A hole to accomodate 14 -inch diameter casing was drilled with a cable-tool rig through 58 feet of alluvium, and the 14 -inch well casing was firmly seated in 5.5 feet of Weber Sandstone, thus sealing unconfined ground water from the well. The static water level in the we11, representing the water table in the alluvium, was 10 feet below land-surface datum (1sd), which is the top of the first joint of the 14-inch diameter casing, as shown in figure 8 . The well was drilled below the 63.5-foot depth of the 14-inch casing as $8 \frac{1}{4}$-inch open hole to a total depth of 300 feet below 1sd. The drilling rate was approximately 3 to 4 feet per hour. The Weber was found to be fractured for the entire depth penetrated by the hole, and ground water under artesian pressure began to flow from the well when it was about 97 feet deep. As the well was deepened, the flow gradually increased; the flow was $150 \mathrm{gpm}$ when drilling was completed at a depth of 300 feet. A 6-inch diameter casing, perforated from 165 to 300 feet, was then installed in the well. The casing was perforated in the interval where the driller reported the greatest 
ground-water yield from the well while it was drilled. Twelve torchcut perforations, $1 / 8 \times 4$ inches, were made in a staggered pattern ... for each foot of casing perforated. The 6-inch diameter casing extends 2.50 feet above $1 \mathrm{sd}$ and is connected to a valved 4-inch diameter horizontal discharge pipe; the lower inside edge of the discharge pipe is 1.70 feet above lsd (fig. 8). A ring seal was seated around the 6-inch casing at the 70-foot depth, and the space surrounding the 6 -inch casing was grouted with cement from the ring seal to 1 sd. The well was surged with the bailer and bailed for about 8 hours, until the water was clear and free of sediment. About 72 hours after the perforated casing was installed, artesian flow from the horizontal discharge pipe was $35.3 \mathrm{gpm}$ and the water level in the 6 -inch casing was 2.02 feet above 1 sd.

To test the well, the valve on the discharge pipe was closed at 2: 30 p.m. July 7, 1970, and the rise of water level in the 6-inch casing was measured and recorded. After 17 hours and 20 minutes of recovery the water level was 2.43 feet above lsd (fig. 9). Rise of the water level was nearly imperceptible at this time, and it was believed to be near static level. The valve on the discharge pipe was then opened and the well was allowed to flow, reaching $35.3 \mathrm{gpm}$ within 2 minutes. Transmissivity of the Weber Sandstone, 4,000 cubic feet per day per foot, is calculated from these data as shown in figure 10 . 


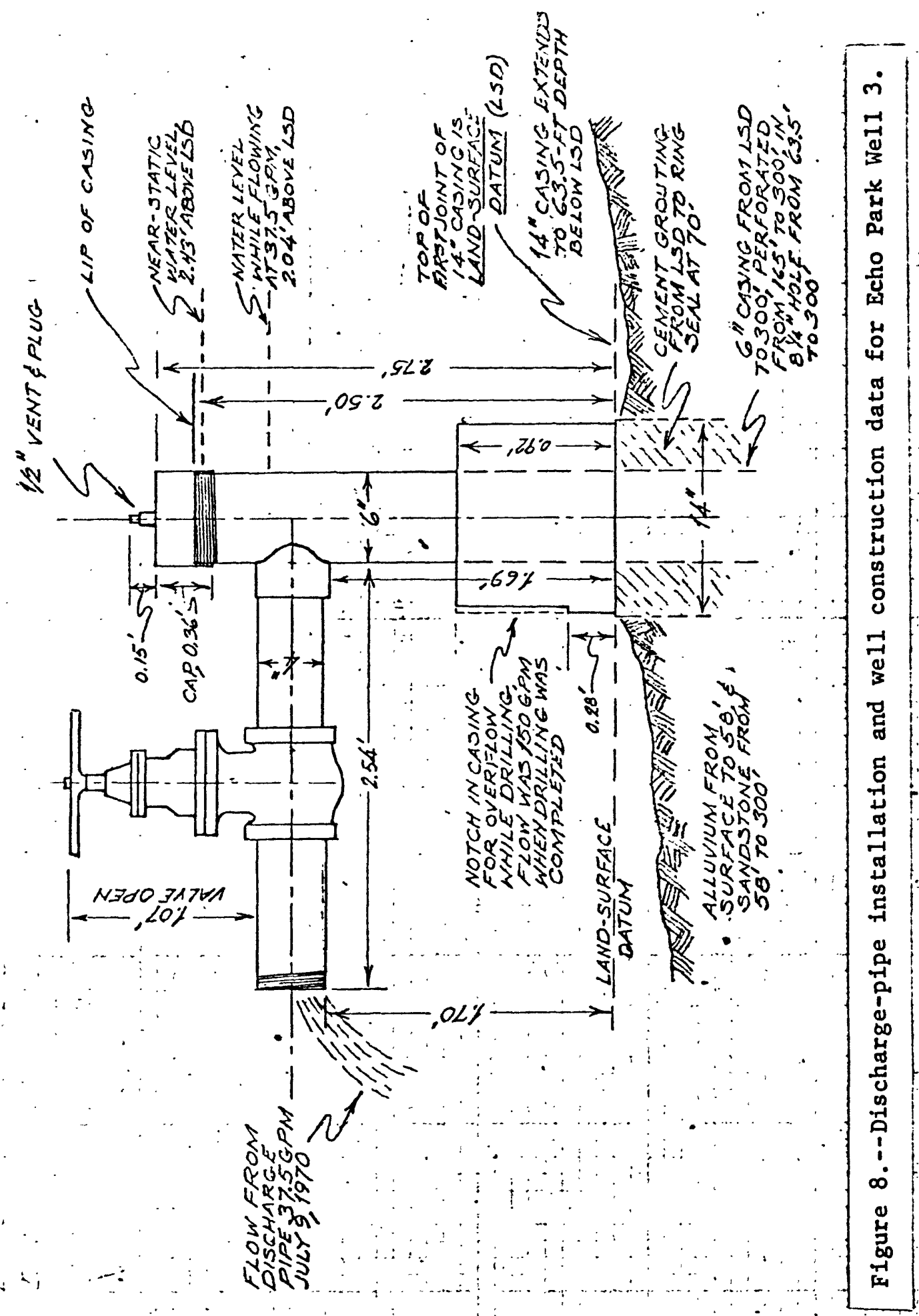


A centrifugal pump, rated at $192 \mathrm{gpm}$, was connected to the well through the open top of the 6 -inch casing and test pumping began at 7: 50 a.m., July 8, 1970. The intitial pumping rate was $64 \mathrm{gpm}$, enough to lower the water level within 2 minutes to 1.67 feet above $1 \mathrm{sd}$, thus causing the well to cease flowing through the 4-inch horizontal discharge pipe. At this pumping rate, drawdown was 0.76 foot, and specific (gallons per minute per foot) capacity of the well was $84 \mathrm{gpm} / \mathrm{ft}$ This pumping rate was maintained for more than 1 hour without further change in the water level (fig. 11). At 9:00 a.m. the pumping rate was increased to $100 \mathrm{gpm}$, lowering the water level to 1.21 feet above $18 \mathrm{~d}$ within 2 minutes. This pumping rate was maintained for 3 hours; during about $21 / 2$ hours of that time the water level declined an additional 0.10 foot to 1.11 feet above $1 \mathrm{sd}$. During the last $1 / 2$ hour of this 3 -hour period there was no further change in the water level. Drawdown was 1.32 feet and specific capacity was $76 \mathrm{gpm} / \mathrm{ft}$ (fig. 11).

At 12:00 noon the pumping rate was increased to $130 \mathrm{gpm}$, lowering the water level to 0.60 foot above 1 d within 2 minutes. This pumping rate was maintained for nearly 4 hours. During the first part of this time after the first 2 minutes, the water level declined 0.13 foot to 0.47 foot above 1sd; there was no change in water level for the final 2 hours of pumping. At this pumping rate, drawdown was 1.96 feet and specific capacity was $66 \mathrm{gpm} / \mathrm{ft}$. At 3:55 p.m. pumping ceased and the valve on the discharge pipe was closed. The total pumping period was 8 hours and 5 minutes. 


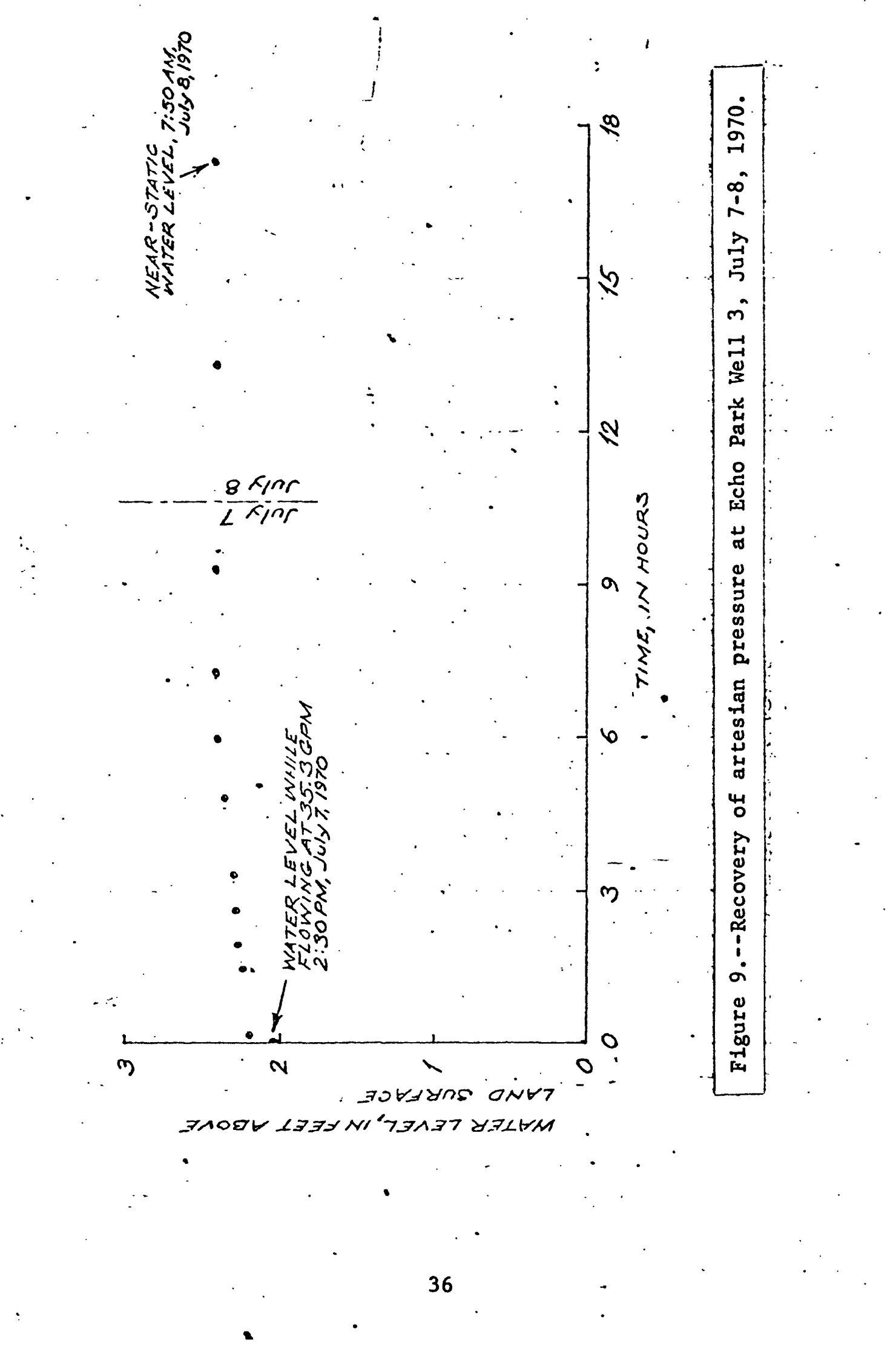



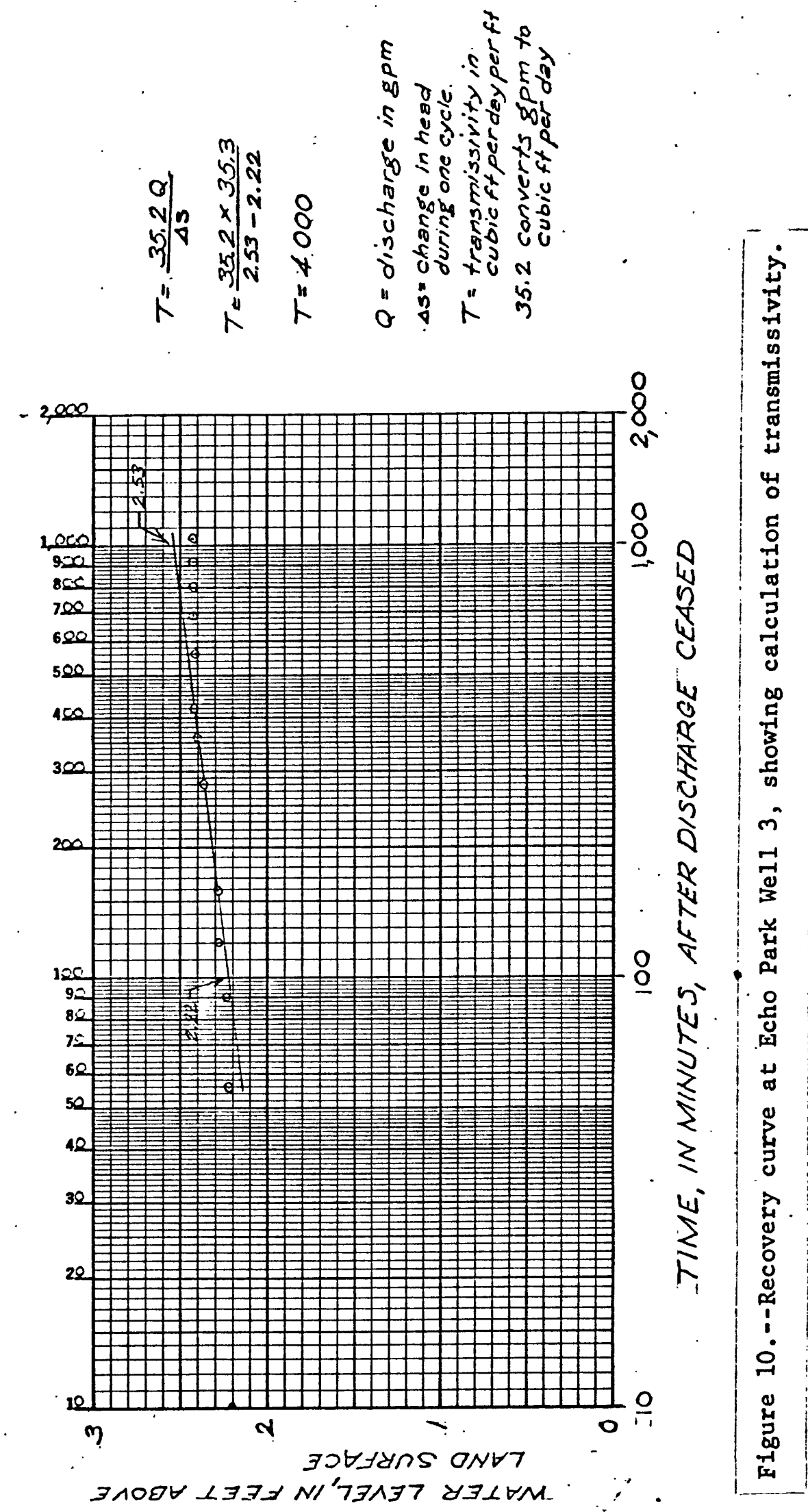


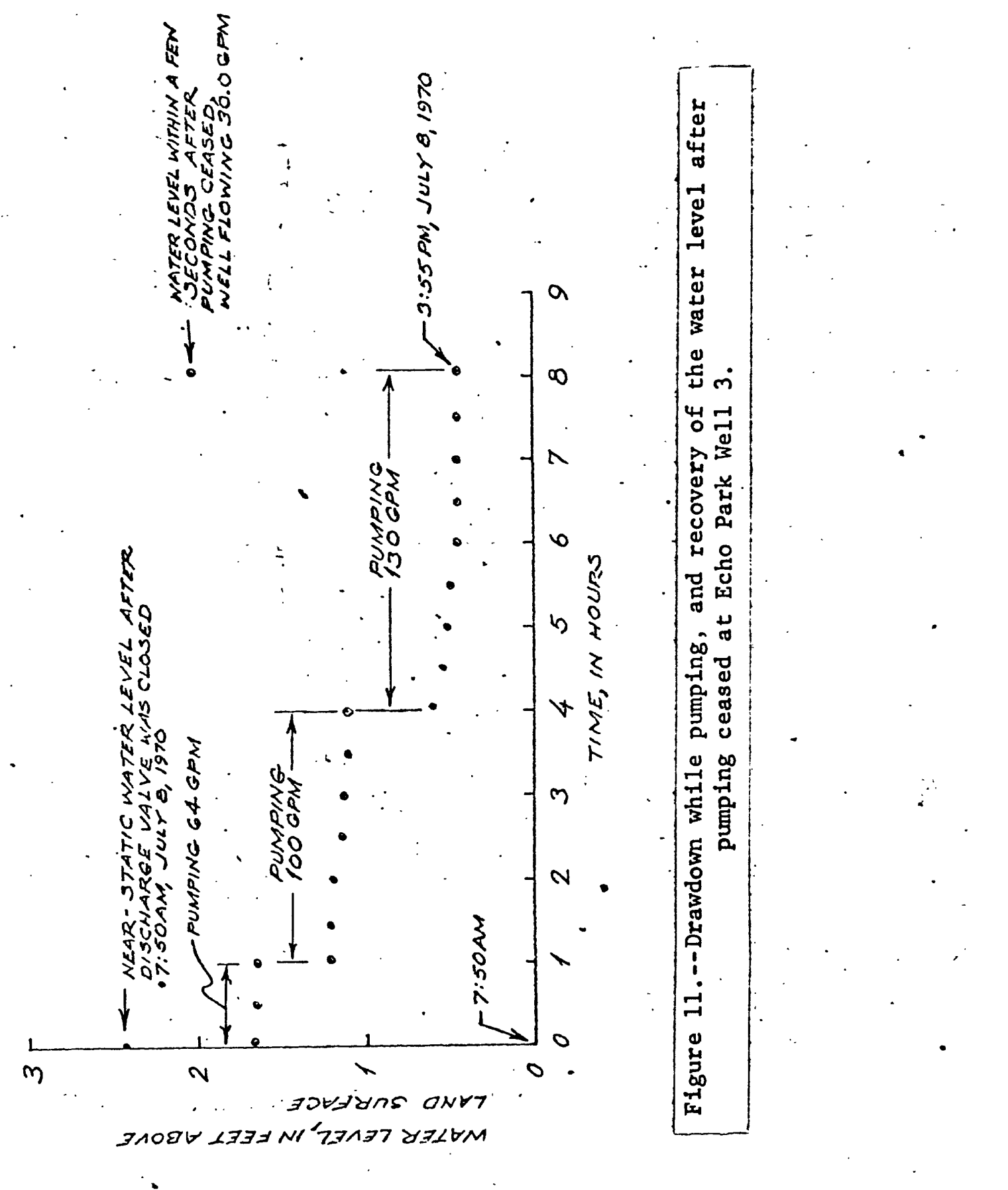


Recovery of the water level to 2.03 feet above lsd was nearly
afier instantancous, $i$ a period of a few seconds during which the water level oscillated. The discharge valve was opened and artesian. flow resumed at $30.0 \mathrm{gpm}$ from 2:01 feet above 1sd. The relationship of discharge to water level in Echo Park Well 3 is shown in figure 12. Flow from the well increased from $30.0 \mathrm{gpm}$ at 2.01 feet above $1 \mathrm{sd}$ to $37.5 \mathrm{gpm}$ at 2.04 feet above $1 \mathrm{sd}$ in the 23 hours and 35 minutes following cessation of pumping ( $\mathrm{fig} .13$ ). This increase is interpreted as an indication that artesian flow from this well will probably be sustained. The increased flow also indicates that the well probably was not completely developed before pumping, and that the well was further developed during pumping. While the well flows at the present rate, no pump and power source are required, and a storage tank is not needed. The rate of flow and the water level will fluctuate slightly with seasonal changes in the artesian pressure within the aquifer, hence the flow and water level should be measured and recorded at least monthly in order to define the range of fluctuations. It is recommended that the well be allowed to flow when needed at the rate sufficient to supply campground requirements, about $15 \mathrm{gpm}$. During freezing weather, a continuous flow of about $3 \mathrm{gpm}$ should be sufficient to prevent damage to the discharge pipe and valve by freezing. This rate of flow will not interfere with any other water supply or source of water in the area. 


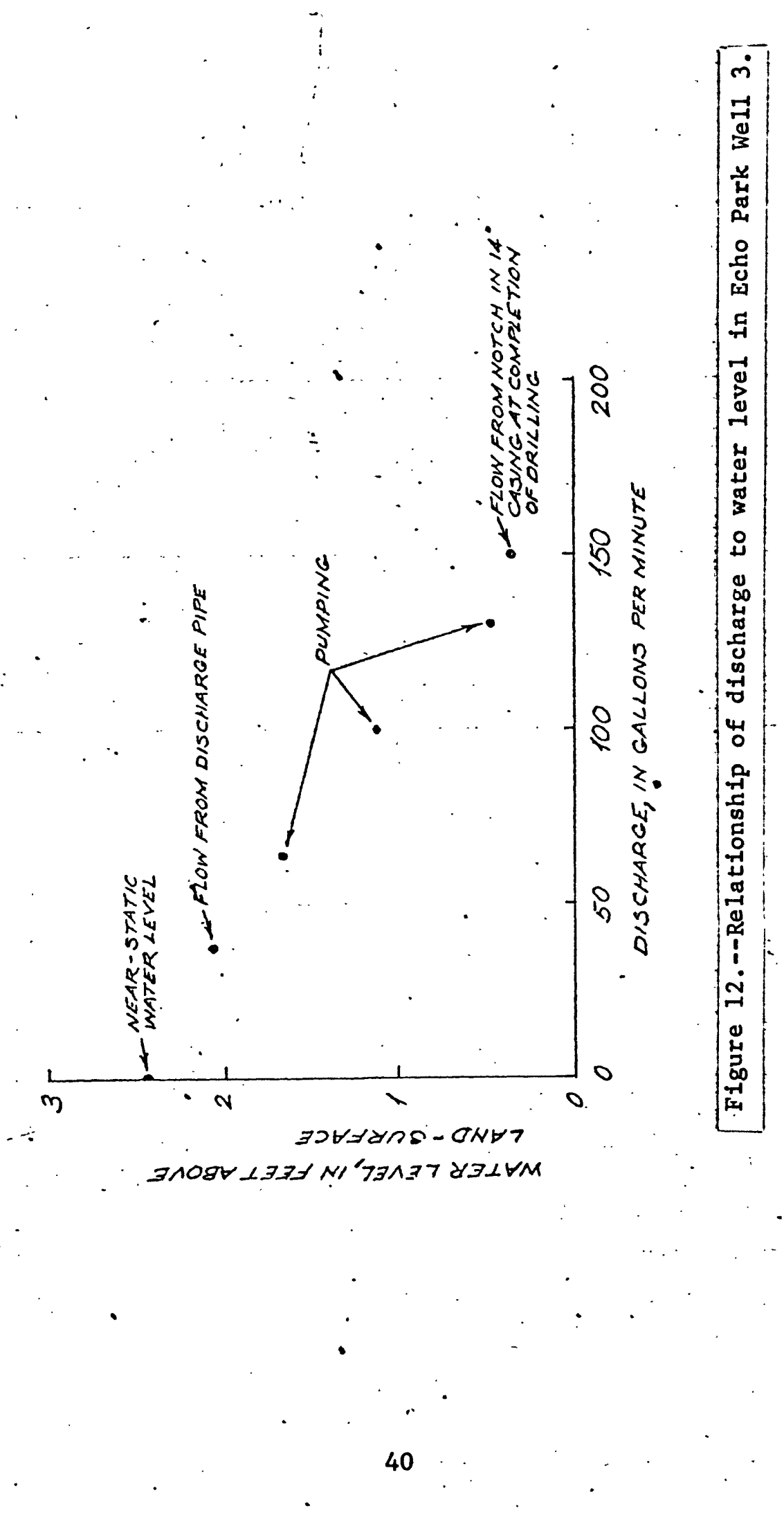




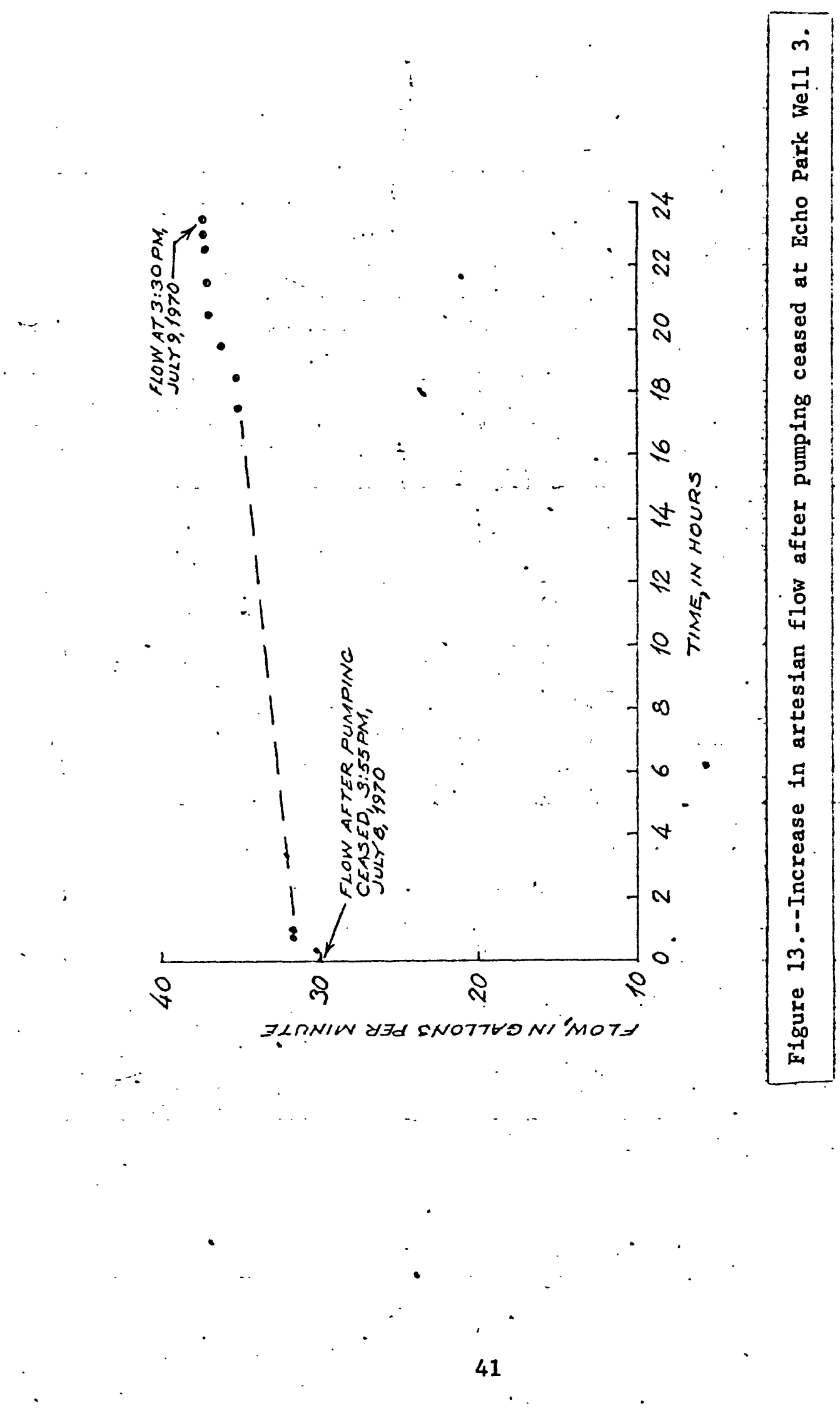


Cessation of flow through the horizontal discharge pipe, due to loss of artesian pressure, is possible. If this should occur, siphon in the well from near land surface to the water pipeline, which is to be installed below land surface, will provide resumption of artesian flow. If the artesian head should ever decline to or below land surface, sufficient water for the ranger station and campground area (about $15 \mathrm{gpm}$ ) can be provided by means of a small centrifugal pump. Water samples for chemical analysis were taken when the well was 220 feet deep and 180 after the recovery of artesian flow to 37.5 gpm following completion of the pumping test. The water was clear without apparent sediment or sand, had no noticeable taste, and its temperature was $13.5^{\circ} \mathrm{C}\left(55.5^{\circ} \mathrm{F}\right)$. Results of chemical anslysis of the sample collected after the test was completed are given in table 13. There was no significant difference in the water at 220 feet and the water from the completed well

In more remote areas, springs serve as emergency sources of water for occasional visitors. Data for two unused wells and of springs in these other areas are given in table 14. Their locations by key number. are given in figure 1. 
Table 14.--Data for wells and springs in other areas of Dinosaur Nat 1onal Monument

\begin{tabular}{|c|c|c|c|c|c|c|c|}
\hline $\begin{array}{l}\text { Key } \\
\text { No. }\end{array}$ & We 11 & $\begin{array}{c}\text { Location } \\
\text { number }\end{array}$ & $\begin{array}{l}\text { Depth } \\
\text { (feet) }\end{array}$ & $\begin{array}{c}\text { Depth to water } \\
\text { (feet) }\end{array}$ & $\begin{array}{l}\text { Yie1d } \\
(g p m)\end{array}$ & Date & Aquifer \\
\hline Colorado & $\bullet$ & & & & & & \\
\hline $24 \quad$ Baker & Cabin We 11 & $(\mathrm{~B}-6-101) 30 \mathrm{bbb}-1$ & 20 & 19 & - & $9-23-69$ & $\begin{array}{l}\text { Park City } \\
\text { Tormation }\end{array}$ \\
\hline Utah & & $\sim$ & & & 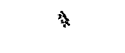 & & \\
\hline Ruple & Ranch Well & $(D-3-25) 32 b a c-1$ & 13 & 12 & - & $9-23-69$ & Alluvlum \\
\hline $\begin{array}{l}\text { Key } \\
\text { No. }\end{array}$ & Spring & $\begin{array}{l}\text { Locati } \\
\text { numbe }\end{array}$ & & $\begin{array}{l}\text { charge } \\
\text { gpm) }\end{array}$ & & Aquffer & \\
\hline
\end{tabular}

\section{Colorado}

\begin{tabular}{|c|c|c|c|c|c|}
\hline 26 & Corral Spring & $(B-6-1.00) 10 \mathrm{dac} S-1$ & 3 & $9-24-69$ & Browns Park Formalion \\
\hline 27 & Baker Spring & $(B-6-101) 30 b c d S-1$ & 12 & $5-1.9-70$ & $\begin{array}{l}\text { Cartra Member (Shinarump } \\
\text { Menber of Chinle Formation) }\end{array}$ \\
\hline 28 & The Seeps & $(B-6-102) 23 \operatorname{ccc} S-1$ & .3 & $5-19-70$ & vo. \\
\hline 29 & Serviceberry Spring & $(B-6-102) 27 \mathrm{dccs}-1$ & 2 & $5-19-70$ & Alluvium \\
\hline 30 & Marthas Spring & $(B-6-102) 28 c d c s-1$ & 2 & $5-19-70$ & Do. \\
\hline 31 & Red Rock Ranch Spring & $(13-6-103) 15 \mathrm{dbaS}-1$ & 3 & $5-19-70$ & $\begin{array}{l}\text { Gartra Member (Shinarump } \\
\text { Member of Chinle Formation) }\end{array}$ \\
\hline 32 & Canyon Overluok Spring & $(B-6-103) 20 c c b s-1$ & .1 & $5-21-70$ & Alluvium \\
\hline 33 & Surveyor Spring & $(B-6-103) 29 a$ ads -1 & 3 & $5-20-70$ & Do. \\
\hline 34 & Limestone Spring & $(B-7-103) 1 b b d s-1$ & 2 & $6-19-70$ & $\begin{array}{l}\text { Yississippian } \\
\text { strata undifferentiated }\end{array}$ \\
\hline 35 & Rippling Brook Spring & $(B-7-103) 6$ adcs -1 & 1 & $9-24-69$ & Browns l'ark Formation \\
\hline 36 & East Hackings Spring & $(B-7-103) 7 \mathrm{dcaS}-1$ & 1 & $9-24-69$ & Do. \\
\hline 37 & West Hackings Spring & $(P-7-103) 7 \mathrm{dcbs}-1$ & 1 & $9-24-69$ & Do. \\
\hline 38 & Dripping Rock Spring & $(13-8-102) ;$ dabs -1 & 2 & $9-24-69$ & Do \\
\hline 39 & Bassett Camp Spring & $(B-8-102) 19 \mathrm{ddaS}-1$ & 2 & $-9-24-69$ & Ml luvium \\
\hline 40 & Buffhams Spring & $(B-8-102) 30 b d c s-1$ & 1 & $6-1.9-70$ & Do. \\
\hline 41 & Chokecherry Spring & $(3-8-102) 31$ bcas -1 & 2 & $6-19-70$ & Do. \\
\hline 42 & R. Buffhams Spring & $(B-8-102) 3$ luad $S-1$ & 3 & $6-19-70$ & Do. \\
\hline \multicolumn{6}{|c|}{ Utah } \\
\hline 43 & Garden Creek Spring & $(D-3-25) 19 d d d S-1$ & 18 & $j-21-i 0$ & Cilen Canyou Sandstone \\
\hline 44 & Mckee Spring & $(\mathrm{b}-4-24) 3$ baas -1 & .1 & $5-21-70$ & $\begin{array}{c}\text { Frontier Sandstone yember } \\
\text { of Mencos Shate }\end{array}$ \\
\hline
\end{tabular}


Evaluation of water resources and hydrology at Deerlodge Park, the Dinosaur Quarry area, the Gates of Lodore area, the Jones Hole area, the Monument Headquarters arca, and test drilling at the Echo Park area show that these areas have potential sites for drilled wells in the Morgan Formation, the Weber Sandstone, or the Gleil Canyon (Navajo) Sandstone. The test well at Echo Park can provide water sufficient for that site. In the Jones Hole area, springs will provide sufficient water supplies for requirements in the near future.

Hydrologic investigations proposed for the fiscal year 1971 include exploration for water sources in remote sections of the monument accessible only by foot, such as Dry Woman Canyon, nutlaw Park, Thanksgiving Gorge, and others. These areas will be explored for springs which will be measured for discharge, selectively sampled for chemical analyses, and evaluated for use by occasional visitors or for emergency use. The hydrologic and geologic data will be compiled as the initial stage of the preparation of the final report. 
Cullins, H. L., 1969, Geologic map of the Mellen Hill quadrangle Rio Blanco and Moffat Counties, Colorad to U.S. Geol. Survey Geo1 Quad. Map GQ-835, scale 1:24,000.

Kinney, D. M., 1955, Geology of the Uinta River-Brush Creek areat Duchesne and Uintah Counties, Utah: U.S. Geol. Survey Bu1131007. $185 \mathrm{p}$.

Sears, J. D., 1962, Yampa Canyon in the Uinta Mountains, Coiorado U.S. Geol. Survey Prof. Paper 374-I, P. 11-133.

Thomas, H. E., 1952, Hydrologic reconnaissance of the Green Rivertith Utah and Colorado: U.S. Geol. Survey Circ $129,32 \mathrm{p}$ Untermann, G. E., and Untermann, B. R., 1954, Geology of Dinosaur National Monument and vicinity, Utah-Colorado:

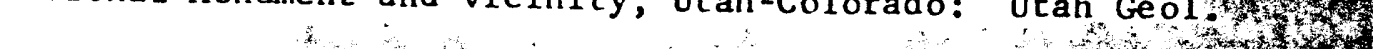
Mineralog. Survey Bull. 42, 228 p.: 1965, Geologic map of the Dinosaur National Monument, Colorado Utah: Dinosaur Nature Assoc. in coop. with Utah Geol, and Mineratos, Survey and Utah Field House of Nat. History, scale 1:62,500 U.S. Public Health Service, 1962, Drinking water stat th Health Service Pub. 956, 61 p.

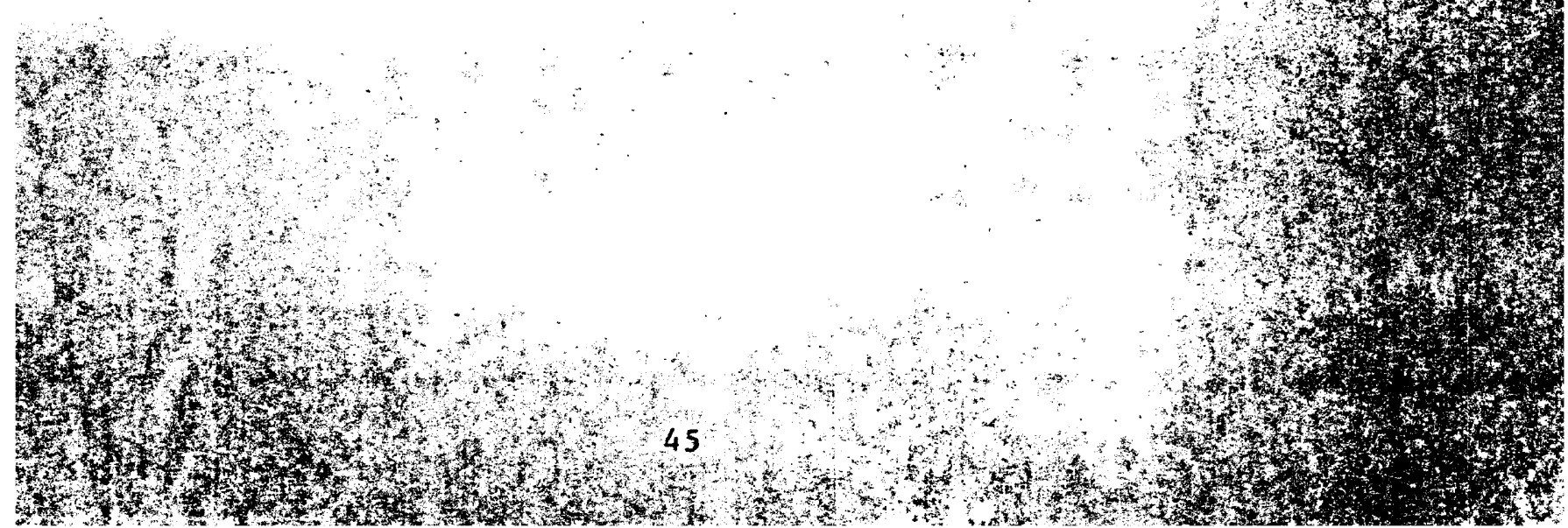


APPENDIX 
APPENDIX A

Units and terminology

The results of chemical analyses and temperature measurements are given in this report in metric units, rather than the more familiar ringlish units. Temperatures are given in degrees $\mathrm{Ce}_{-}^{-} \cdot \dot{i} \mathrm{us}$, and concentrations are reported in milligrams per liter or milliequivalents per Ixtor.

Degrees Celsius $\left({ }^{\circ} \mathrm{C}\right)$ are the units used for reporting temperature in the metric system. One degree Celsius is equal to $9 / 5$ degrees Fahrenheit, and the freezing point of water is $0^{\circ}$ on the Celsius scale. The following table may be used to convert the temperature data given in this report to the more familiar Fahrenheit scale:

Unnumbered table (next page) here.

Milligrams per liter (mg/l) is the base unit for expressing the concentration of chemical constituents in solution, and it represents the weight of solute per unit volume of water. For concentrations of less than about $7,000 \mathrm{mg} / 1$, this unit is numerically very nearly equal to the unit parts per million (ppm), which was formerly used by the U.S. Geological Survey. 
TEMPERATURE-CONVERSION TABLE

Temperatures in ${ }^{\circ} \mathrm{C}$ are rounded to nearest 0.5 degree. Underscored temperatures are exact equivalents. To convert from ${ }^{\circ} \mathrm{F}$ to ${ }^{\circ} \mathrm{C}$ where two lines have the same value for ${ }^{\circ} \mathrm{F}$, use the line marked with an asterisk (*) to obtain equivalent ${ }^{\circ} \mathrm{C}$.

\begin{tabular}{|c|c|c|c|c|c|c|c|c|c|c|c|c|c|}
\hline${ }^{\circ} \mathrm{C}$ & ${ }^{\circ} \mathrm{F}$ & ${ }^{\circ} \mathrm{C}$ & 官 & ${ }^{\circ} \mathrm{C}$ & $\bullet \vec{F}$ & ${ }^{\circ} \mathrm{C}$ & $\bullet$ & ${ }^{\circ} \mathrm{C}$ & $\cdot F$ & ${ }^{\circ} \mathrm{C}$ & $\bullet$ & ${ }^{\circ} \mathrm{c}$ & F \\
\hline-20.0 & -4 & -10.0 & 14 & 0.0 & $\underline{32}$ & 10.0 & 50 & 20.0 & 68 & 30.0 & 86 & 40.0 & 104 \\
\hline-19.5 & -3 & -9.5 & $\overline{15}$ & $+\overline{0.5}$ & $\overline{33}$ & $\overline{10.5}$ & $\overline{51}$ & $\overline{20.5}$ & $\overline{69}$ & $\overline{30.5}$ & $\overline{87}$ & $\overline{40.5}$ & $\overline{105}$ \\
\hline-19.0 & -2 & -9.0 & 16 & 1.0 & 34 & 11.0 & 52 & 21.0 & 70 & 31.0 & 88 & 41.0 & 106 \\
\hline-18.5 & -1 & -8.5 & 17 & 1.5 & 35 & 11.5 & 53 & 21.5 & 71 & 31.5 & 89 & 41.5 & 107 \\
\hline$-18.0 *$ & 0 & $-8.0 *$ & 18 & $2.0 *$ & 36 & $12.0 *$ & 54 & $22.0 *$ & 72 & $32.0 *$ & * 90 & $42.0 *$ & 108 \\
\hline-17.5 & 0 & -7.5 & 18 & 2.5 & 36 & 12.5 & 54 & 22.5 & 72 & 32.5 & 90 & 42.5 & 108 \\
\hline-17.0 & 1 & -7.0 & 19 & 3.0 & 37 & 13.0 & 55 & 23.0 & 73 & 33.0 & 91 & 43.0 & 109 \\
\hline-16.5 & 2 & -6.5 & 20 & 3.5 & 38 & 13.5 & 56 & 23.5 & 74 & 33.5 & 92 & 43.5 & 110 \\
\hline-16.0 & 3 & -6.0 & 21 & 4.0 & $3 \ddot{9}$ & 14.0 & 57 & 24.0 & 75 & 34.0 & 93 & 44.0 & 111 \\
\hline-15.5 & 4 & -5.5 & 22 & 4.5 & 40 & 14.5 & 58 & 24.5 & 76 & 34.5 & 94 & 44.5 & 112 \\
\hline-15.0 & $\underline{5}$ & -5.0 & 23 & 5.0 & 41 & 15.0 & 59 & 25.0 & 77 & 35.0 & 95 & 45.0 & 113 \\
\hline-14.5 & $\overrightarrow{6}$ & -4.5 & $\overline{24}$ & $\overline{5.5}$ & $\overline{42}$ & $\overline{15.5}$ & $\overline{60}$ & $\overline{25.5}$ & $\overline{78}$ & $\overline{35.5}$ & $\overline{96}$ & $\overline{45.5}$ & $\overline{114}$ \\
\hline-14.0 & 7 & -4.0 & 25 & 6.0 & 43 & 16.0 & 61 & 26.0 & 79 & 36.0 & 97 & 46.0 & 115 \\
\hline-13.5 & 8 & -3.5 & 26 & 6.5 & 44 & 16.5 & 62 & 26.5 & 80 & 36.5 & 98 & 46.5 & 116 \\
\hline-13.0 & 9 & -3.0 & 27 & 7.0 & 45 & 17.0 & 63 & 27.0 & 81 & 37.0 & 99 & 47.0 & 117 \\
\hline-12.5 & 10 & -2.5 & 28 & 7.5 & 46 & 17.5 & 64 & 27.5 & 82 & 37.5 & 100 & 47.5 & 118 \\
\hline$-12.0 *$ & 10 & $-2.0 *$ & 28 & $8.0 *$ & 46 & $18.0 *$ & 64 & $28.0 *$ & 82 & $38.0 *$ & 100 & $48.0 *$ & 118 \\
\hline-11.5 & 11 & -1.5 & 29 & 8.5 & 47 & 18.5 & 65 & 28.5 & 83 & 38.5 & 101 & 48.5 & 119 \\
\hline-11 & 12 & -1.0 & 30 & 9.0 & 48 & 19.0 & 66 & 29.0 & 84 & 39.0 & 102 & & 120 \\
\hline-10.5 & 13 & -0.5 & 31 & 9.5 & 49 & 19.5 & 67 & 29.5 & 85 & 39.5 & 103 & 49.5 & 121 \\
\hline
\end{tabular}

For temperature conversions beyond the limits of the table, use the equations $\mathrm{C}=$ $0.5556(F-32)$ and $F=1.8\left({ }^{\circ} \mathrm{C}\right)+32$. The formulae say, in effect, that from the freezing point of water $\left(0^{\circ} \mathrm{C}, 32^{\circ} \mathrm{F}\right.$ ) the temperature in ${ }^{\circ} \mathrm{C}$ rises (or falls) $5^{\circ}$ for every rise (or fall) of $9^{\circ} \mathrm{F}$. 
The capacity of an aquifer to transmit and store water is described by the transmissivity of the aquifer, the hydraulic conductivity of the water-bearing material, and the storage coefficient of the aquifer.

Transmissivity (T) is the rate at which water is transmitted through a unit width of the aquifer under a unit hydraulic gradient. The units for I are cubic feet per day per foot $\left(f t^{3} / d a y / f t\right)$, which reduces to $\mathrm{ft}^{2} / \mathrm{day}$. The term transmissivity replaces the term coefficient of transmissibility, which was formerly used by the U.S. Geological Survey and which was reported in units of figallons per day per foot. To convert a value for coefficient of transmissibility to the equivalent value of transmissivity, multiply by 0.134 ; to convert from transmissivity to coefficient of transmissibility, multiply by 7.48 .

The hydraulic conductivity (K) of a water-bearing material is the volume of water that will move through a unit cross section of the material in unit time under a unit hydraulic gradient. The units for $\underline{K}$ are cubic feet per day per square foot $\left(f t^{3} / \mathrm{day} / \mathrm{ft}^{2}\right)$, which reduces to $\mathrm{ft} / \mathrm{day}$. The term hydraulic conductivity replaces the term field coefficient of . permeability, which was formerly used by the U.S. Geological Survey and which was reported in units of gallons per day per square foot. To convert a value for field coefficient of permeability to the equivalent value of hydraulic conductivity, multiply by 0.134 ; to convert from hydraulic conductivity to coefficient of permeability, multiply by 7.48 . 
The storage coefficient (S) of an aquifer is the volume of water it releases from or takes into storage per unit surface area of the aquifer per unit change in head. $S$ is a dimensionless number. Under confined conditions, $\underline{S}$ is typically small, generaily between 0.001 and 0.00001 . Under unconfined conditions, $\underline{S}$ is much larger, typically from 0.05 to 0.30 . 
Sections within a township

Tracts within a section

R. $23 E$.
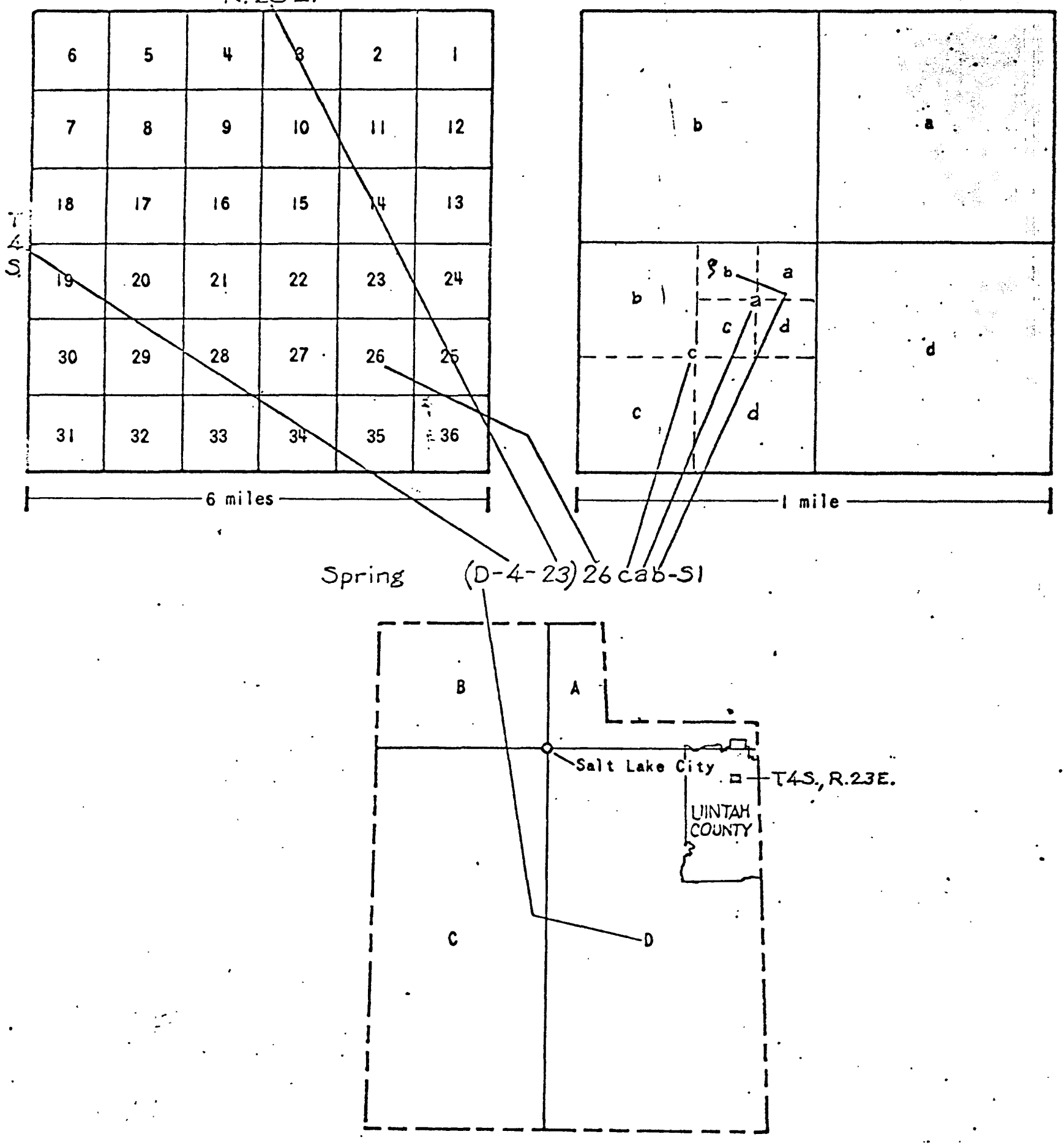

Well- and spring numbering system used in Utah 
APPENDIX ${ }^{\prime} \mathrm{C}$.

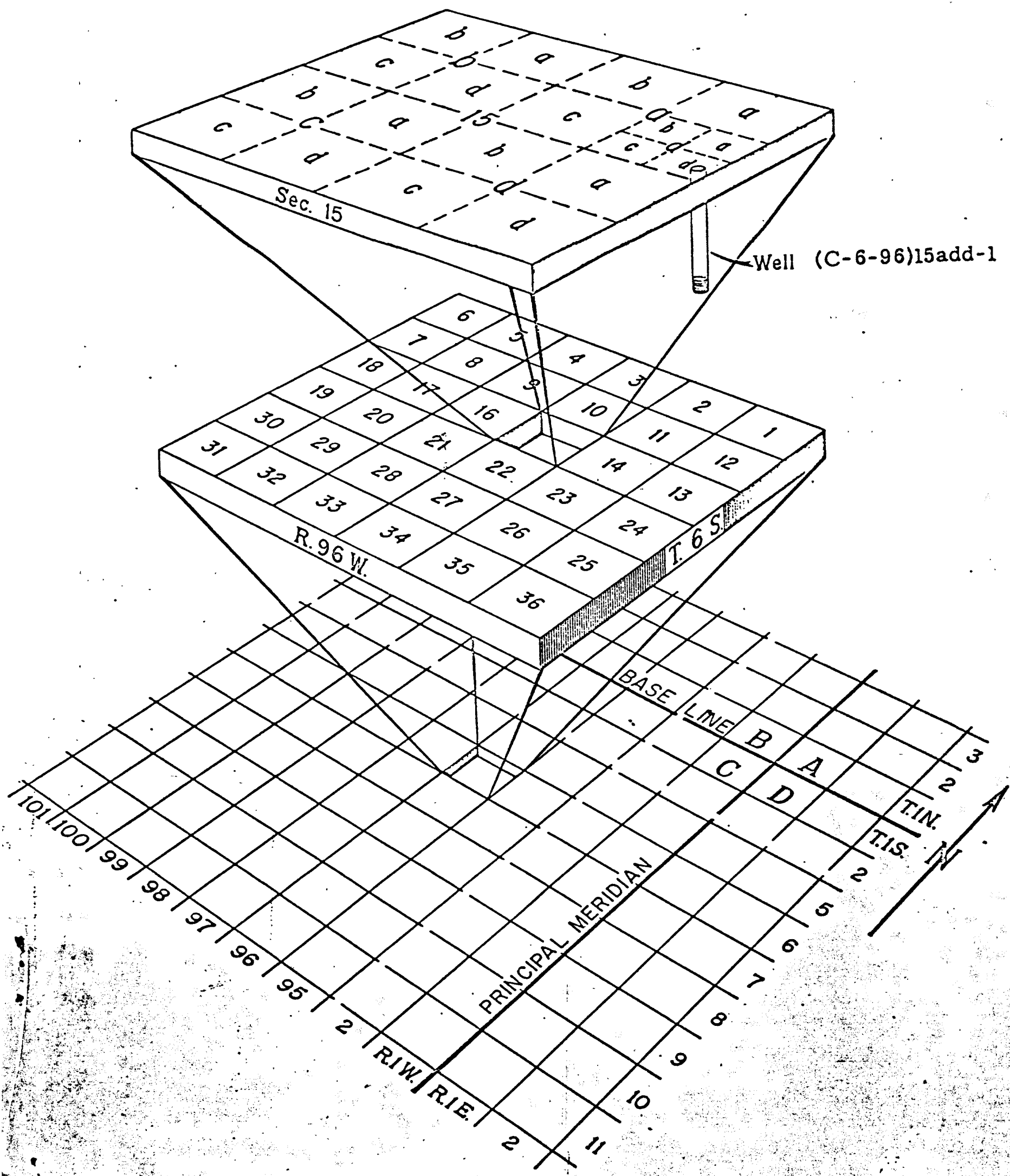

Well- and spring-numbering system used in Colorado 